\title{
The Migration of Fear: An Analysis of Migration Choices of Syrian Refugees
}

\author{
Mehmet Balcilar \\ Eastern Mediterranean University, Famagusta, North Cyprus, via Mersin, 10, Turkey, University \\ of Pretoria, South Africa, Montpelier Business School, Montpelier, France \\ Jeffrey B. Nugent ${ }^{\dagger}$ \\ University of Southern California, Los Angeles, CA, 90089-0253 US. \\ E-mail: nugent@ rcf.usc.edu
}

March 30, 2018

\begin{abstract}
The current literature on forced migration offers only limited knowledge of how each of the different consequences of war, such as damage to property and casualties to family members, and the services provided to the refugees in the host country, affect the difficult choices that refugees subsequently must make as to when and where to migrate from their location as refugees. This paper contributes to that literature by studying the effects of armed violence in Syria on the intentions of Syrian refugees in Turkey to return to Syria, stay in Turkey or move on to Europe and elsewhere. The study is based on three waves of a survey of Syrian refugees in Turkey. Special attention is given to the impacts of war (loss of home, property damage and casualties) and the duration of stay and quality of services received as refugees in Turkey, as well the individual characteristics of the refugees (e.g., gender, age, education, and income). The results show that (1) the longer and greater the level of violence in the country of origin, and the longer the time spent outside of Syria, the lower the likelihood that the refugee will want to return to Syria; (2) the longer the time the refugee has spent in Turkey, the higher is the probability of permanent settlement in another European country; and (3) the more and higher quality of services provided to the refugees, the more likely they are to remain in Turkey. The results offer insights into the design of international policy for dealing with the violence and the handling of refugees.
\end{abstract}

Keywords: refugees, forced migration, labor market, employment, immigration, logit model, civil war, Syria, Turkey.

JEL Codes: F22, J10, J15, R23, C25, N45

The authors express their thanks to AFAD for allowing us to utilize their three rounds of the survey, and to Marcus Marktanner, Youssouf Kiendrebeogo, Saurabh Singhal, Moritz Kappler, Dawoon Jung, Shawkat Hammoudeh and other participants at the joint session of the AEA and MEEA in Chicago, and at the $92^{\text {nd }}$ Annual Conference of the Western Economic Association in San Diego where previous versions of the paper have been presented, and especially the editor and two referees of this journal for their extremely relevant and helpful comments and suggestions.

${ }^{\dagger}$ Corresponding Author. E-mail: nugent@usc.edu; Tel: +1 213 740-2107; Fax: +1 213 740-8543 


\section{Introduction}

With the forcibly displaced population in the world having grown from 42.5 million in 2011 to 67.3 million in 2017 and the number of international refugees from 10.4 to 26.1 million over the same period, the world is facing the highest levels of forced displacement since World War II. Over the last seven years, the conflict in Syria has contributed far more refugees (5.5 million) and internally displaced persons (IDPs) (more than 11 million) to the world totals than any other country ${ }^{1}$. At present, well over $60 \%$ of the 5.5 million Syrian refugees (some 3.38 million) are registered in Turkey, all arriving since 2011, and these numbers continue to grow.

The conflict in Syria has also caused over 450,000 deaths, reducing life expectancy for those in Syria from 73.8 in 2008 to 70.07 by $2015 .^{2}$ It is clear, therefore, that the Syrian refugees in Turkey and elsewhere have been subject to large but varying amounts of violence, including serious injuries to themselves, loss of life of relatives and neighbors, and damage to or total loss of their homes and property. Yet, very little has been learned about the effects of such violence on the future aspirations of the refugees with respect to migration, including their intentions to return to Syria or to migrate to other countries.

The main objectives of the present study are (1) to extend the existing literature on forced migration by connecting the violence that the refugees and their families experienced in Syria to their decisions to flee from Syria and (2) to identify factors affecting their subsequent choices for migrating back to Syria or to Europe or elsewhere. Objective (1) is important since, as we will show in the literature review section, for the most part this has not been possible in previous forced migration experiences from around the world. Objective (2) is important because of the rapidly rising costs of handling the refugees estimated to be 35 billion US dollars ${ }^{3}$, and the frequent inability to get aid to many of the over 6 million displaced persons within Syria who lack sufficient access to food, health care and schools.

\footnotetext{
${ }^{1}$ In terms of accumulated numbers, refugees from Syria are still behind those from Afghanistan and Iraq.

2 These figures are from the World Bank World Development Indicators. From an alternative source (The CIA World Fact Book) the drop was even sharper to 68.4 in 2014. Outside of possibly Uganda over the course of its civil war from 1985-1995 a fall of 3.8 years in life expectancy this is the largest fall for any country in recent history.

${ }^{3}$ World Bank, MENA Quarterly Economic Brief, January 2016: The Economic Effects of War and Peace.
} 
It aims to contribute to these objectives by taking advantage of information from Syrian refugees in Turkey concerning both violence in their country of origin, the timing of their arrival in Turkey, and the type of services they are receiving in Turkey, and their expressed intentions about further migration. The primary source of this information is three waves of the Survey on Syrian Refugees in Turkey carried out by AFAD, the Turkish agency responsible for dealing with Natural and Man Made Disasters. These surveys (hereafter AFAD Surveys) are based on random samples of Syrian refugees in Turkey (both those living inside and outside of refugee camps). Since the economic cost of the Syrian war, including caring for the growing number of refugees in Turkey, Lebanon, Jordan, Iraq, Egypt and other countries receiving these refugees, has been rising rapidly, the results generated in this paper should be useful in evaluating the benefits and costs of alternative approaches to solving the Syrian refugee problem. ${ }^{4}$

Our results show that violence, both in the form of damage to homes and deaths of family members, has contributed to both flight from Syria and to the reduced likelihood that Syrian refugees in Turkey are considering migration back to Syria. They also show that time in Turkey and the quality of services provided to them contribute to their desire to migrate either elsewhere in Turkey itself or to Europe and beyond.

The remainder of the study is organized as follows. Section II presents a brief survey of the literature on Conflict or Forced Migration, identifying those areas in which this study is intended to contribute. Section III provides background on the Syrian conflict, identifies the main phases of the violence in Syria and the arrival of refugees in Turkey, and describes the character and randomization of the data obtained from the three waves of AFAD Surveys between 2013 and late 2015. Section IV identifies the main hypotheses concerning the determinants of future migration aspirations and briefly describes the data (including descriptive statistics). Section V identifies the estimation methods, further steps needed to deal with interdependencies among the variables and measurement issues, and presents all the empirical results. Section VI summarizes the empirical

\footnotetext{
${ }^{4}$ One other relevant study on Syrian refugees in Turkey (based on a different survey) and to be discussed below is Fabbe et al (2017). While there have also been surveys of Syrian refugees in both Jordan (e.g. Doocy et al., 2015) and Lebanon (Jefee-Balloul et al., 2014; Benage et al., 2015; and Hassan et al., 2016), these have been largely confined to health, and relatedly to access to health services. To our knowledge, however, none of these has collected data relevant to the central issues of this paper concerning the prospects and possible timing of further migration.
} 
findings, and finally Section VII provides a short discussion of some possible implications for policy and future research.

\section{Existing Literature on Forced Migration and the Gaps to be Filled}

Most of the literature on forced migration is based on aggregate (mostly state-level) data. These studies are commonly referred to as large-n studies, typically identifying various determinants and effects, both economic (such as Gross Domestic Product (GDP) per capita, its growth rate, unemployment, income inequality, and economic discrimination), and non-economic (such as natural disasters and conflict-related factors or human rights violations). Essentially, these large-n studies have been used to draw inferences about individual decisions on whether to migrate or stay on the assumption that people can make rational choices even under the extremely violent conditions of war and that the macro-level patterns reflect micro-level influences (Schmeidl, 1997; Apodaca, 1998; Davenport et al., 2003; Moore and Shellman, 2004, 2006, 2007; Neumayer, 2005; Melander and Öberg, 2006, 2007; Shellman and Moore, 2007; Edwards 2009; Song, 2012; Verwimp and Maystadt, 2015). ${ }^{5}$

The few studies on forced migration that use individual level data have made use of some of the same explanatory variables used in the aggregate studies, such as the level of violence, economic, social, political, and physical aspects of the environment, and individual characteristics such as gender, age, education, income, etc. Among these are Massey et al. (2010) on Nepal; Engel and Ibáñez (2007), Ibáñez and Vélez (2008) on Colombia; Czaika and Kis-Katos (2009) on Aceh Province in Indonesia; Alvarado and Massey (2010) on migration from several countries of Latin America to the United States; Bohra-Mishra and Massey (2011) and Adhikari (2013) again both on Nepal. ${ }^{6}$ Even these few studies using individual level data have generally not been able to go much deeper in explaining conflict migration than the studies using aggregate data. In the case of Czaika and Kis-Katos (2009), this is in part because the observations were only at the village level. In other cases, the explanation is that the measures used were largely the same as those in the macro-level literature such as on the level of education and its effects on refugees. A couple of interesting exceptions are Vogler and Rotte (2000) which demonstrated the relevance of the

\footnotetext{
${ }^{5}$ See also Clark (1989) for a review of variables found to have power in predicting refugee flows.

${ }^{6}$ Verwimp and Brück (2009) provide a nice review of some of the micro-level studies on forced migration.
} 
individual's social networks in decisions to migrate, and Massey et al. (2010) which showed the relevance of time duration effects (which we find also to be relevant to the Syrian case). Some of these individual level studies on forced migration (e.g., Ibáñez and Vélez, 2008; Czaika and KisKatos, 2009) have involved only internal displacement not international migration and hence the migration decisions of refugees.

While some of these studies have used quantitative measures of violence and allowed for nonlinearities in such effects as we do in the present study, seldom have such studies examined the impacts of casualties to family members and of direct damage to homes and the quality of services provided to the refugees in their host country on their forthcoming choices about the timing and direction of subsequent migration. The major objective of this study is to investigate the links between various individual characteristics, the different results of violence in the country of origin, interdependencies therein and the time and services received in the host country on the one hand, and their future migration aspirations on the other.

Another relevant literature is that prompted by psychological views of those like Bowles (2008) and others who noticed that people who had experienced wars with "outsiders" seemed to undergo attitudinal change in the direction of showing greater trust and cooperation, at least among “insiders". This led political scientists and economists to design surveys aimed at quantitatively assessing these psychological and attitudinal changes. These surveys, which have almost exclusively been directed to resident national populations in the aftermath of wars around the globe (as opposed to refugees), have expanded to the extent that Bauer et al (2016) carried out a metaanalysis of a number of these surveys. Indeed, their conclusion is that, rather consistently across these surveyed countries, wartime conflict fosters cooperation and perhaps greater equity, at least among the "insiders". Although these surveys treat trust and cooperation very nicely, they do not touch on migration choices.

One important study along these lines that is focused (like the present study) on Syrian refugees in Turkey is Fabbe et al (2017). Since their interest is in rather particular political attitudes (such as their views about the incumbent Assad regime, its main opposition, the desire to avoid politics altogether or simply to volunteer in their present community), they deem it important to distinguish between various kinds of experiences that led the refugees to flee Syria. They focus on one such common experience, namely, having had one's home destroyed by indiscriminate barrel bombs used by the Assad government, usually in various locations under opposition control 
between Jan 2014 and March 2015. They argue that the indiscriminate nature of barrel bombing, even if propagated against people in regions largely opposed to the Assad regime, would make those forced out of Syria by this bombing more likely to say that "No group represents me", to avoid taking positions on politics and to be more willing to volunteer in providing services for fellow Syrians. Their application of this particular "treatment" of subset of Syrian refugees in Turkey indeed provides results supporting this rationale. ${ }^{7}$ Yet, since the refugees subjected to this particular treatment were often currently living together in several common locations with others who had come from the same neighborhoods, especially from the city of Aleppo, at least some of this greater willingness to cooperate could perhaps be attributed to their long-time spent as neighbors.

Finally, another set of studies particularly relevant to refugee locational choices are those seeking to identify effects of refugee presence on host populations and their economies. In particular, Ruiz and Vargas-Silva (2013, 2015) and Ozden and Wagner (2014) have shown that the effects of forced migration on the host countries' labor markets for their nationals may not be as negative as one would think. This is because the exogenous inflow of workers has the effect of lowering labor costs, increasing output of labor-intensive products which in turn increases income and the demand for labor. While most such research has been limited to Asia and Africa, Del Carpio and Wagner (2015) have recently investigated the effects of Syrian refugees on the market for Turkish workers. To do so they have combined locational information concerning the number of Syrian refugees by subregion within Turkey, as well as on their governorates of origin from one round of the AFAD Surveys (and hence their distance to each of 26 subregions in Turkey), with information on each of these 26 different subregions from the Turkish Household Labor Force Surveys for 2011 and 2014. They use distance from Syrian location of origin to the largest city in each of these subregions in Turkey as an instrument to help them identify causal effects on Turkish labor markets. Notably, their results show varying effects. On the one hand, they show that the influx of Syrians has led to considerable displacement of poorly educated, low-skilled, female parttime workers, especially in agriculture. On the other hand, however, it has encouraged additional production and income and occupational upgrading of Turkish workers.

\footnotetext{
7 This explanation was derived from the earlier work of Kalyvas (2006) based on numerous case studies from different conflicts, and another more recent one by Tyner (2016) for Syria in particular, showing that indiscriminate violence by an incumbent in a given location is more likely when that incumbent no longer has control over that location.
} 
So, too, Altindag et al (2017) have shown that the locations with larger percentages of Syrian refugees have been ones in which local firms have grown more rapidly, providing additional employment opportunities to Turks as well as refugees. They, too, make use of an instrument (indeed a different one, namely, the predicted inflows of Syrian workers based on the past presence of Arabic speakers in the area) to mitigate endogeneity in the form of reverse causality whereby migrants would be going to where the jobs are located. We believe that the results of our empirical analysis may contribute to the explanation of these otherwise somewhat surprising findings.

\section{Syrian Civil War, Violence,}

As is well known, the Arab Spring events began in Tunisia in 2011 but soon spread to Egypt, Yemen, Bahrain, Morocco, Syria, Yemen, Libya, and Syria. In the case of Syria, what started as peaceful demonstrations relatively early in 2011 turned into violent repression and then, in return, led to greater militancy by dissidents in late 2011, with violence spreading around the country in certain locations over time and continuing in some locations until the present.

Precise assessment of the destruction due to the war is not easy, especially since most information on this comes primarily through the partial observations of the various humanitarian organizations in the country. Assessment of the physical damage to property ${ }^{8}$ is especially partial and incomplete. While there is more objective data on casualties of the war by date and province in Syria, even this data is incomplete and the estimates vary from one source to another. Figure 1, however, provides a reasonably accurate time path of the verified casualties of the war from March 2011. It identifies late 2011, summer of 2012, August 2013, and March 2015 as the periods with the sharpest upward spikes in such casualties, but with occasional smaller spikes in casualties even as recently as early $2017 .{ }^{9}$ While refugee flows to Turkey do not coincide precisely with these spikes, the correlation between refugee arrival in Turkey and casualties has been quite high. Figure 2 shows the corresponding time path of the stock of Syrian refugees in Turkey from early 2011.

\footnotetext{
${ }^{8}$ However, Marx (2016) assesses building damage based on remote sensing approach using Landstat images.

${ }^{9}$ The single most violent month was August, 2012 which included an intense air bombing campaign in Aleppo, Syria's largest city and its former commercial capital. The jump in the summer of 2013 was in large part attributable to the fall of the northwestern city of Idlib to Islamist groups led by al-Nusra, and the upward jump in fatalities in September 2015 occurred when Russian troops entered Syria and Russian war planes began intensive bombing.
} 
Figure 1: Monthly verified casualties of Syrian civil war (Mar 2011-Mar 2016)

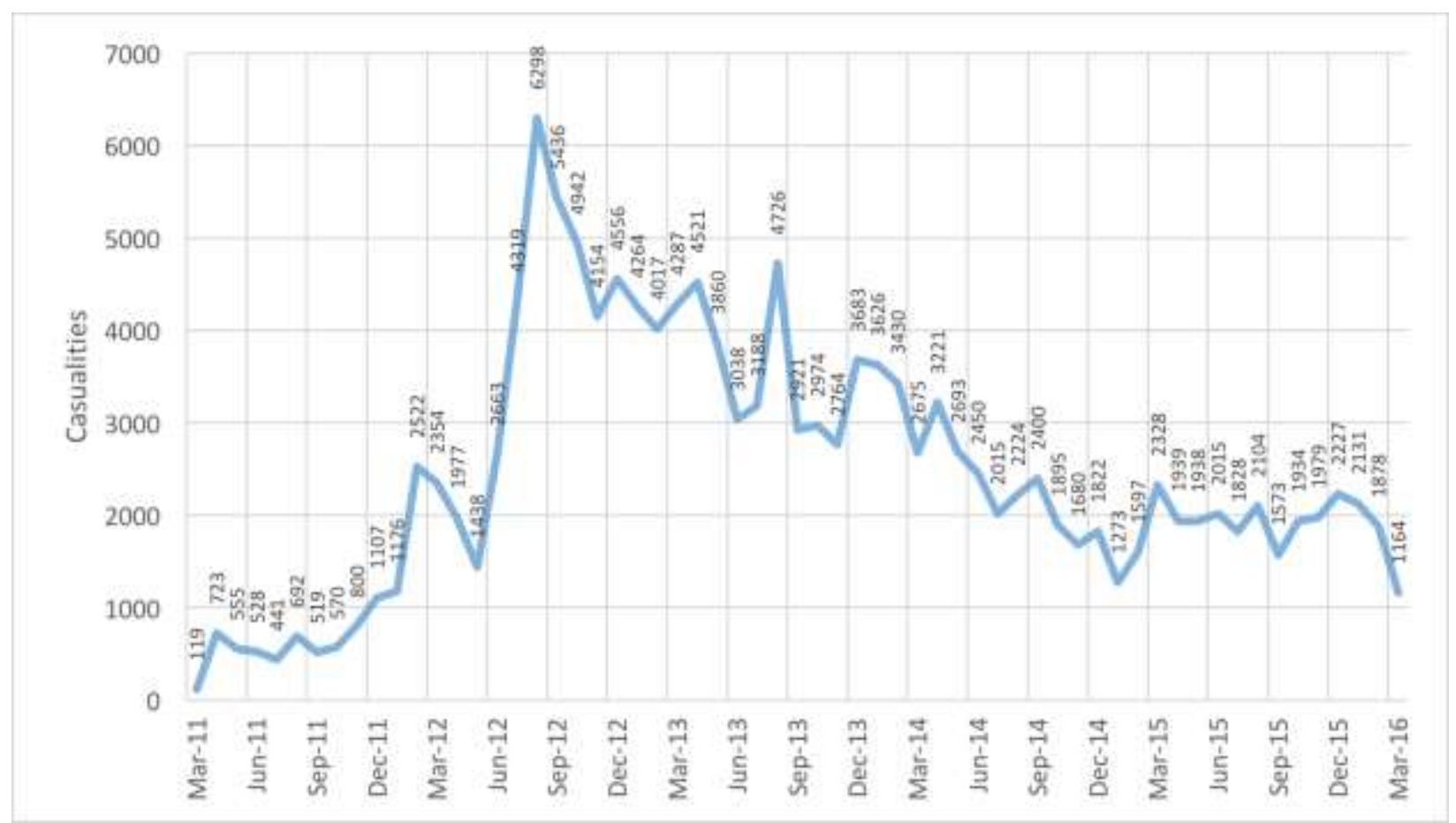

Source: Humanitarian Tracker, Syria Tracker Database (http://www.humanitariantracker.org) and Price et al. (2014).

Figure 2: Syrian refugees in Turkey (Dec. 2011 - Jun. 2016)

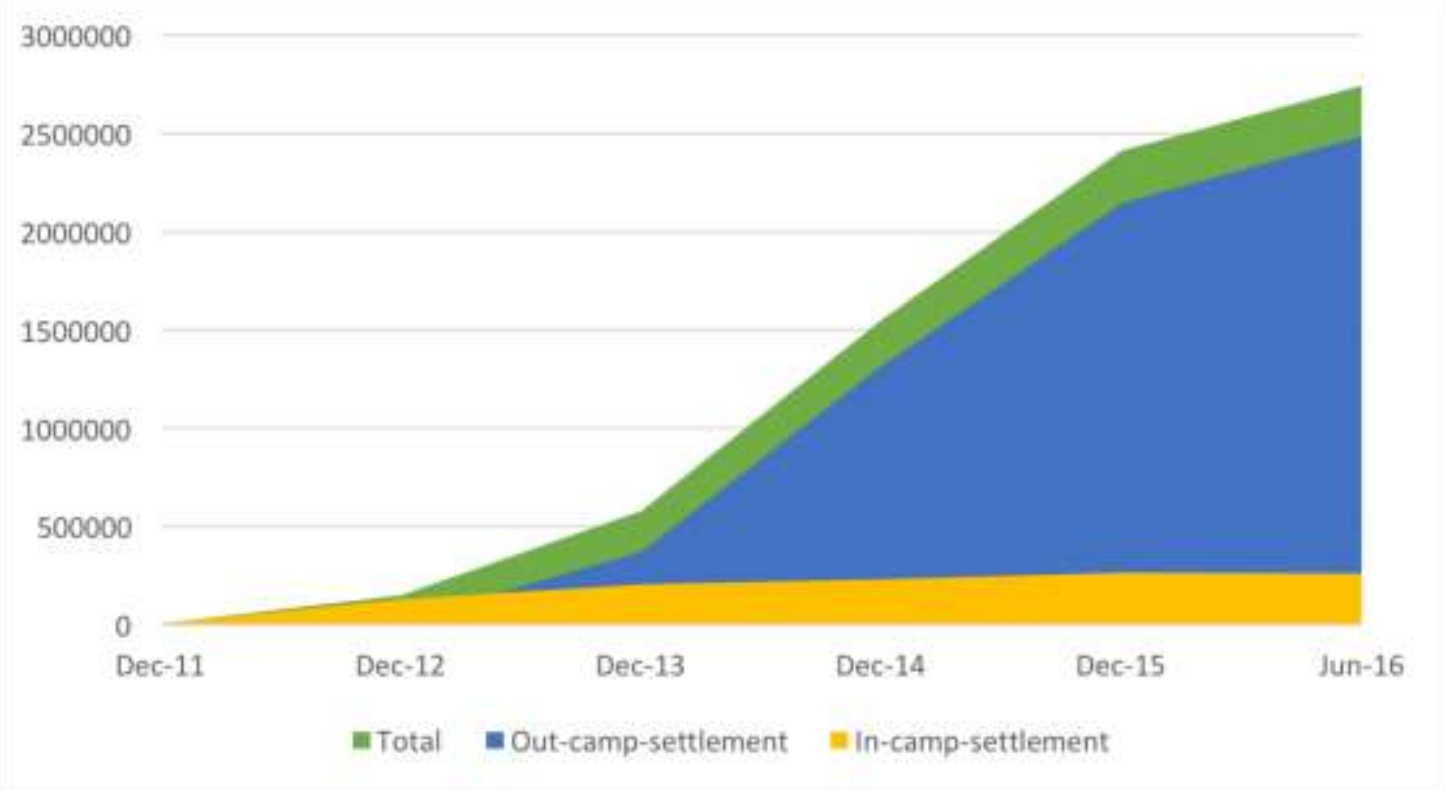

Source: AFAD (Disaster and Emergency Management Authority), http://www.afad.gov.tr.

Thanks to the three waves of the AFAD Surveys of Syrian refugees in Turkey (Wave 1 undertaken in June-July 2013, Wave 2 in September 2014 and Wave 3 in December 2015), 
considerably more can be learned about the relation between the violence outcomes on individual refugees and their subsequent further choices about migration from the AFAD Surveys than from other sources. While some of the questions posed in the surveys were unique to a particular wave of the survey, many others were common to two or three of them. Similarly, while some of the questions were directed to individuals, others were focused on the households as a whole. Since the questions on war damage and migration on which our paper is focused were mainly based on the household portion of the surveys, our analysis is primarily based on the household level information obtained from the household heads including their expectations and preferences in future migration choices. Even when limiting our attention to household heads or other decisionmaking individuals at the household level, pooling the data obtained from the different waves of the survey provides us with a sample of 4433 household heads from which to identify the key determinants of their future migration aspirations.

To assure their representativeness, the randomized selection in the surveys took place at three different levels, first by type of location (in camps, or out of camps in cities and towns), second by community (selected from each of three different refugee density groups), and then by household (selected from within each of the selected communities and location types). This had the effect of equalizing the probability that any Syrian refugee would be surveyed across location types and community sizes. Overall, the selected refugee households came from 13 provinces in Turkey which accounted for over 80 percent of all the Syrian refugees registered in Turkey.

The various tables in our on-line Appendix provide descriptive statistics and other information on various aspects of the sampled Syrian refugee households and individuals. Tables A1-A3 document male-female differences in several respects such as age, education and marital status. Not surprisingly, about 75 percent of the individuals identified as household heads were male. Collectively, the tables highlight many different ways in which the rather horrendous effects of the violence in Syria on the refugees can be appreciated. Specifically, Table A3 shows that over 75 percent of the refugees identified Security and Health as the major reason for their departure from Syria. Table A4 shows that in the most recent wave of the survey (2015) 37.5 percent of the refugee heads of households said that at least one of their family members had been killed in Syria and 13 percent of them said that at least two family members had been killed in Syria. Similarly, Table A5 shows that 51.8 percent of them said that their home in Syria had "collapsed" (meaning it had been totally destroyed) and over 32 percent more said that their home had been at least 
partially damaged (most of the rest did not know the situation of their homes). Table A6 shows that over 36 percent of the heads interviewed in the most recent survey indicated that one or more adult members of their household had sleeping disorders. Table A7 shows that the longer they have been living as refugees in Turkey, household heads seem less keen on returning to Syria. While many say they would do so "when it becomes possible", the percentage who have said that they would never return to Syria has risen from 6 percent in the 2013 to 9.3 percent in 2015, and very few seem optimistic that return will soon be possible.

In comparing the patterns of responses to the relevant questions about violence in Syria across households and individuals of differing characteristics across survey years, it became quite clear to us that there could be considerable interdependencies among many of these variables that would need to be taken into consideration in our analysis. This will be reflected in the methods identified in Section IV to mitigate the estimation biases arising from such interdependencies.

\section{Descriptive Statistics and Hypotheses to be Tested Linking the Data to Our Objectives}

For purposes of the present study, however, and considering that it is household heads who would be primarily responsible for making the subsequent migration decisions, in Table 1 we present the descriptive statistics on all the variables utilized in our analysis based on responses from the full sample of household heads across all three waves of the survey.

The table begins with the four different Migration Decisions anticipated: namely, to return to Syria (RETURN), to migrate elsewhere than to Syria (MIGRATE), to return to Syria as soon as possible (RTNASAP) and to migrate to another country (MIGRATEINT). Each of these measures is defined as bivariate $(0,1)$ dummy variables. RETURN is coded $=1$ if and only if the respondent responds that he or she would return to Syria under at least one of the following circumstances: (i) as soon as possible (designated as RTNASAP), (ii) when the conflict in Syria ends, (iii) when the conflict in his/her home city ends, or (iv) when the government of Syria changes. ${ }^{10}$ Otherwise, it is coded to 0. MIGRATE is defined as a desire to migrate to another location, whether internal to Turkey, or to another country. Since the length of time for such a return to be possible is by no means clear, by no means does RTNASAP imply an immediate return to Syria. MIGRATEINT is

\footnotetext{
10 The empirical results are robust to taking response to each option as the dependent variable and ignoring the responses to other options. These results are available from the authors upon request.
} 
a more specific variant on MIGRATE, i.e., indicates an intent to migrate internationally, i.e., to a country other than Syria or Turkey.

Table 1: Descriptive statistics for the binary regression variables

\begin{tabular}{|c|c|c|c|c|c|}
\hline Variable & $n$ & Mean & Std. Dev. & Min & $\operatorname{Max}$ \\
\hline RETURN & 4433 & 0.878 & 0.327 & 0 & 1 \\
\hline MIGRATE & 4433 & 0.151 & 0.358 & 0 & 1 \\
\hline RTNASAP & 4433 & 0.022 & 0.147 & 0 & 1 \\
\hline MIGRATEINT & 4433 & 0.016 & 0.124 & 0 & 1 \\
\hline MALE & 4433 & 0.750 & 0.433 & 0 & 1 \\
\hline FEMALE & 4433 & 0.250 & 0.433 & 0 & 1 \\
\hline NOSHELTER & 4433 & 0.668 & 0.471 & 0 & 1 \\
\hline SHELTER & 4433 & 0.332 & 0.471 & 0 & 1 \\
\hline NDEATHS & 1374 & 3.121 & 4.975 & 1 & 80 \\
\hline INCOME & 4106 & 22356.480 & 43329.370 & 0 & 1500000 \\
\hline RFGMONTHS & 4384 & 37.154 & 12.288 & 3 & 60 \\
\hline DAMAGE & 4433 & 0.627 & 0.484 & 0 & 1 \\
\hline DEATH & 4433 & 0.321 & 0.467 & 0 & 1 \\
\hline IN-CAMP & 4433 & 0.205 & 0.406 & 0 & 1 \\
\hline WATER AND HYGIENE & 4433 & 4.014 & 0.204 & 1 & 5 \\
\hline HEALTH SERVICE & 4433 & 4.956 & 0.126 & 1 & 5 \\
\hline SECURITY & 4433 & 4.139 & 0.231 & 1 & 5 \\
\hline RFGTIME: 1-12 months & 4433 & 0.672 & 0.470 & 0 & 1 \\
\hline RFGTIME: 13-24 months & 4433 & 0.183 & 0.386 & 0 & 1 \\
\hline RFGTIME: 25-36 months & 4433 & 0.072 & 0.259 & 0 & 1 \\
\hline RFGTIME: 37-48 months & 4433 & 0.046 & 0.210 & 0 & 1 \\
\hline RFGTIME: 49-60 months & 4433 & 0.015 & 0.121 & 0 & 1 \\
\hline INCOME: 0-10000 & 4433 & 0.324 & 0.468 & 0 & 1 \\
\hline INCOME: 10001-20000 & 4433 & 0.319 & 0.466 & 0 & 1 \\
\hline INCOME: 20001-30000 & 4433 & 0.149 & 0.356 & 0 & 1 \\
\hline INCOME: 30001-40000 & 4433 & 0.045 & 0.208 & 0 & 1 \\
\hline INCOME: 40001-50000 & 4433 & 0.045 & 0.207 & 0 & 1 \\
\hline INCOME: 500001+ & 4433 & 0.045 & 0.207 & 0 & 1 \\
\hline EDUCATION: Illiterate & 4433 & 0.165 & 0.371 & 0 & 1 \\
\hline EDUCATION: Literate & 4433 & 0.095 & 0.294 & 0 & 1 \\
\hline EDUCATION: Primary school & 4433 & 0.273 & 0.446 & 0 & 1 \\
\hline EDUCATION: Elementary school & 4433 & 0.215 & 0.411 & 0 & 1 \\
\hline EDUCATION: High school & 4433 & 0.121 & 0.326 & 0 & 1 \\
\hline EDUCATION: Bachelor/graduate & 4433 & 0.115 & 0.319 & 0 & 1 \\
\hline
\end{tabular}

Note: The table reports the number of observations ( $n$ ), arithmetic mean (Mean), standard deviation (Std. Dev.), the minimum (Min), and the maximum (Max) of the variable. 
To take maximum advantage of the individual and household level data available in the AFAD Surveys of Syrian refugees, Table 1 also includes descriptive statistics on several possible determinants of these different Migration Decisions that had been used in some of the countrylevel analyses identified in Section II above. These include individual and household characteristics (such as gender (FEMALE and MALE), and income status. Given our interest in linking these decisions to their experience with violence in Syria, we also include some of the variables reflecting evidence of such violence on the individual household (as asserted to by the household head). These are: numbers of deaths in the family (NDEATHS), a dummy for the death of one or more family members (DEATH), whether that head asserts that there would no longer be a shelter in Syria to which he (or she) could return (NOSHELTER) ${ }^{11}$, and whether that home in Syria has been at least partially damaged (DAMAGE).

To reflect the effects of the location in Turkey and quantity and quality of services offered to the refugee household in Syria, we also include a dummy variable for location in a camp (INCAMP), and categorical measures for the quality of each of the following services: WATER AND HYGIENE, HEALTH SERVICES and SECURITY, each measured on a 1-5 Likert Scale. Finally, as a variable possibly reflecting both time in Turkey, and thus the consumption of services provided there, and the accumulating repercussions of the violence in Syria, we include the time lived as a refugee in the current host country (RFGTIME). ${ }^{12}$ Experience elsewhere in the world has frequently shown that more protracted conflicts are more likely to push refugees to move on further and not to return to their location of origin than those which are ended quickly. The variable RFGTIME is defined in terms of one-year intervals with classes defined as 1-12 months, 13-24 months, 25-36 months, 37-48 months, and 49-60 months. These one-year time intervals by which RFGTIME is classified are deemed preferable to the use of an integer time variable since changes in migration and return decisions need not be accurately observed in monthly intervals. We do, however, as an alternative measure use the number of months lived as a refugee (RFGMONTHS).

As can be seen from the maximum and minimum values in the full sample for most variables in Table 1, most of them are 0,1 dummy variables. While across the three waves almost 88 percent of the household heads indicated they would consider a return to Syria (RETURN) (in most cases

\footnotetext{
${ }^{11}$ NOSHELTER is a dummy variable that takes a value of 1 if there is no longer a shelter in Syria to which the refugee could return. We define the SHELTER as 1-NOSHELTER to indicate the availability of shelter on return to Syria ${ }^{12}$ The variable RFGTIME is based on RFGMONTHS variable in Table 1, which is the number of months lived as refugee in Turkey.
} 
only when this was deemed possible), only 2.2 percent indicated they would consider returning to Syria as soon as possible (RTNASAP). 15.1 percent indicated they would like to migrate but only 1.6 percent said they would like to migrate outside of Turkey (MIGRATEINT). On average, only 32 percent of the heads reported one or more deaths in the family due to the violence (DEATH), but the average number of deaths in the family was well over 2. Almost two-thirds of the household heads reported at least some damage to their homes in Syria (DAMAGE). As to the location of the refugees in Syria and services received, notice that only a little over 20 percent were located in the generally less desired location, in camps (IN-CAMP), and the surprisingly high scores were assigned to WATER AND HYGIENE, SECURITY and especially HEALTH SERVICE. The remaining explanatory variables listed in the table include Education (measured in terms of levels completed by the household head, Income levels (in intervals of 10,000 Syrian pounds) earned in the last 12 months.

In order to motivate the empirical analysis to be carried out in the next section, in the following paragraphs we identify the most important hypotheses (based in part on the previous findings on forced and other migration in the large n country studies reviewed in Section II and also on rather straight forward intuition concerning the way the benefits and costs of these alternative migration decisions would vary by individual, household and other characteristics).

H1 Impacts of the Violence in Syria Measures

a. In general, and especially considering that the violence inflicted on Syrians has been greater that in virtually any other civil war in the post WWII period and there is as yet no sign that the violence will be stopped and peace restored we would expect that the greater are the consequences of that violence to the individual household measured by NDEATHS, DEATH, and DAMAGE, the less likely the household would want to return to Syria (RETURN) and especially to RTNASAP. This is not to deny that damage from barrel bombing as suggested by Fabbe et al (2017) could be somewhat different than other sources of damage.

b. Conversely, the greater these consequences, the more likely the household would want to MIGRATE and MIGRATEINT.

\section{H2 Impacts of Individual and Household Characteristics}

a. Since proximity to family (and perhaps for marriage) is likely to be more important and career employment opportunities less important for Syrian females, we expect the Female dummy 
(FEMALE) to have a positive effect on RETURN and RTNASAP but a negative one on MIGRATE and MIGRATEINT.

b. Assuming that the returns to human capital outside of Syria could well be higher than what they have been or likely to be in the near future inside Syria, we would expect that household heads with more Education and High Income Earned in the last 12 months while still in Syria would be expected to have higher probabilities of MIGRATE and MIGRATEINT but lower ones of RETURN and RTNASAP.

H3 Impacts of the Location and Quality of Services to Refugees in Turkey

a. As the location in Turkey improves, i.e., being located in towns and cities (where employment opportunities are more accessible), and the quality of services received (WATER AND HYGIENE, SECURITY and HEALTH SERVICE) improves, we would expect them to reduce RETURN and RTASAP and quite possibly also MIGRATEINT, making it likely the refugees would want to stay in Turkey, though likely wanting to migrate to a larger city.

b. Since refugees could be expected to become better adjusted to conditions and possible job and other opportunities outside of Syria and to have established friendships with neighbors, the longer the time they spend as refugees in Turkey, Time as a refugee (RFGTIME) would be expected to lower RETURN and RTNASAP and to raise MIGRATE but not MIGRATEINT.

\section{Estimation Methods and Empirical Results}

Given that all four migration outcome variables identified in Table 1 are measured as 0,1 dummy variables, we shall presently go on estimate each of them with logit regressions using the maximum likelihood method, and usually with a relatively complete set of explanatory variables. However, given the above noted interdependencies visible to us in our careful inspection of the descriptive statistics among the gender, education, income, DAMAGE, DEATH, and migration intentions in different waves of the AFAD Surveys in the Appendix tables, we deem it important to test for the independence of the explanatory variables to be included in any single estimating equation. Also we deem it important to omit those explanatory variables which are either consistently not statistically significant or highly interrelated.

Table 2 presents the results of these independence tests for all pairs of variables listed in Table 1 and identified above. For each such pair, the table reports several different tests of independence, namely, the Pearson Chi-Square test, the likelihood ratio (LR) test, the linear-by- 
linear association (LLA) test, Cramer's Phi test, Cramer's V test, and the contingency coefficient (CC). Each of these is reported in a different column of the table. Based on the results reported in Table 2, for most pairs of variables we can strongly reject the hypothesis of independence (and uniformly by all the different tests in most cases). Only for the variable pairs Physiological EffectSurvey Year, Migration Plan-Shelter Existence, and Migration Plan-Gender, do we not reject the null of independence. ${ }^{13}$

Table 2: Pairwise test of independence between demographic, socio-economic and conflict-related variables

\begin{tabular}{|c|c|c|c|c|c|c|c|}
\hline Variable Pairs & $\begin{array}{r}\text { Pearson } \\
\text { Chi-Square }\end{array}$ & LR & LLA & Phi & Cramer's V & $\mathrm{CC}$ & $n$ \\
\hline Income-Survey Year & $710.434^{* * *}$ & $696.612^{* * *}$ & $38.740^{* * * *}$ & $0.416^{* * * *}$ & $0.294^{* * * *}$ & $0.384^{* * *}$ & 4106 \\
\hline Flee Reason-Survey Year & $30.005^{* * *}$ & $31.143^{* * *}$ & 0.989 & $0.089^{* * *}$ & $0.089^{* * *}$ & $0.089^{* * *}$ & 3761 \\
\hline Return Condition-Survey Year & $336.112^{* * *}$ & $481.524^{* * *}$ & $88.137^{* * *}$ & $0.281^{* * * *}$ & $0.199^{* * *}$ & $0.271^{* * *}$ & 4243 \\
\hline Home Damage-Survey Year & $99.992^{* * * *}$ & $198.984^{* * *}$ & $66.853^{* * * *}$ & $0.214^{* * *}$ & $0.151^{* * *}$ & $0.209^{* * *}$ & 4370 \\
\hline Deaths-Survey Year & $10.561^{* * *}$ & $10.350^{* * *}$ & $0,027^{* * *}$ & $0.049^{* * *}$ & $0.049^{* * *}$ & $0.049^{* * *}$ & 4371 \\
\hline Shelter Existence-Survey Year & $19.530^{* * *}$ & $20.047^{* * * *}$ & $19.846^{* * *}$ & $0.073^{* * *}$ & $0.073^{* * *}$ & $0.073^{* * *}$ & 3685 \\
\hline Migration Plan-Survey Year & $41.321^{* * * *}$ & $46.281^{* * * *}$ & $36.590^{* * *}$ & $0.106^{* * *}$ & $0.106^{* * *}$ & $0.105^{* * *}$ & 3686 \\
\hline Physiological Effect-Survey Year & 0.366 & 0.410 & 0.410 & -0.011 & 0.011 & 0.011 & 3712 \\
\hline Education-Survey Year & $88.691^{* * * *}$ & $91.343^{* * * *}$ & $25.951^{* * * *}$ & $0.143^{* * * *}$ & $0.101^{* * * *}$ & $0.141^{* * *}$ & 4364 \\
\hline Sleeping Disorder-Survey Year & $77.564^{* * *}$ & $76.490^{* * *}$ & $51.735^{* * *}$ & $0.166^{* * *}$ & $0.166^{* * *}$ & $0.164^{* * *}$ & 2801 \\
\hline Deaths-Survey Year & $75.121^{* * *}$ & $83.937^{* * * *}$ & 0.089 & $0.234^{* * *}$ & $0.165^{* * *}$ & $0.228^{* * *}$ & 1374 \\
\hline Return Condition-Deaths & $29.494^{* * *}$ & $28.913^{* * *}$ & $3.001^{*}$ & $0.084^{* * * *}$ & $0.084^{* * *}$ & $0.083^{* * *}$ & 4214 \\
\hline Return Condition-Home Damage & $76.597^{* * *}$ & $79.998^{* * * *}$ & $4.513^{* *}$ & $0.135^{\text {*** }}$ & $0.067^{* * *}$ & $0.134^{* * *}$ & 4211 \\
\hline Migration Plan-Deaths & $8.205^{* *}$ & $8.077^{* *}$ & $8.125^{\text {**** }}$ & $0.047^{* *}$ & $0.047^{* *}$ & $0.047^{* *}$ & 3664 \\
\hline Migration Plan-Home Damage & $14.656^{*}$ & $14.359^{*}$ & 0.956 & $0.063^{*}$ & $0.045^{*}$ & $0.063^{*}$ & 3659 \\
\hline Return Condition-Shelter Existence & $26.381^{* * * *}$ & $26.911^{* * * *}$ & $4.560^{* * *}$ & $0.089^{* * * *}$ & $0.086^{* * *}$ & $0.086^{* * *}$ & 3530 \\
\hline Migration Plan-Shelter Existence & 1.529 & 1.534 & 1.360 & 0.021 & 0.021 & 0.021 & 3617 \\
\hline Return Condition-Income & $139.077^{* * *}$ & $150.961^{* * *}$ & $21.393^{* * *}$ & $0.188^{* * *}$ & $0.084^{* * *}$ & $0.184^{* * *}$ & 3950 \\
\hline Migration Plan-Income & $26.333^{* * *}$ & $25.856^{* * *}$ & $14.838^{* * * *}$ & $0.088^{* * *}$ & $0.062^{* * *}$ & $0.087^{* * *}$ & 3417 \\
\hline Return Condition-Province of Origin & $241.287^{* * *}$ & $233.694^{* * *}$ & $12.694^{* * * *}$ & $0.239^{* * * *}$ & $0.107^{* * *}$ & $0.232^{* * *}$ & 4234 \\
\hline Return Condition-Gender & $9.925^{*}$ & $10.470^{*}$ & $3.103^{*}$ & $0.049^{*}$ & $0.049^{*}$ & $0.048^{*}$ & 4215 \\
\hline Return Condition-Education & $60.011^{* * * *}$ & $57.164^{* * * *}$ & 2.213 & $0.120^{* * *}$ & $0.053^{* * *}$ & $0.119^{* * *}$ & 4202 \\
\hline Migration Plan-Province of Origin & $47.267^{* * *}$ & $43.715^{* *}$ & 0.928 & $0.113^{* * *}$ & $0.080^{* * *}$ & $0.113^{* * *}$ & 3677 \\
\hline Migration Plan-Gender & 0.392 & 0.397 & 0.357 & 0.010 & 0.010 & 0.010 & 3662 \\
\hline Migration Plan-Education & $25.329^{* * *}$ & $24.649^{* * * *}$ & $17.304^{* * *}$ & $0.083^{* * *}$ & $0.059^{* * *}$ & $0.083^{* * *}$ & 3666 \\
\hline Migration Target-Gender & $34.084^{* * *}$ & $31.348^{* * * *}$ & 0.002 & $0.142^{* * * *}$ & $0.142^{* * *}$ & $0.140^{* * *}$ & 1694 \\
\hline Migration Target-Education & $69.840^{* * *}$ & $71.597^{* * * *}$ & $26.280^{* * * *}$ & $0.204^{* * *}$ & $0.091^{* * *}$ & $0.200^{* * *}$ & 1683 \\
\hline Migration Target-Income & $230.306^{* * *}$ & $207.051^{* * *}$ & $78.030^{* * *}$ & $0.376^{* * *}$ & $0.168^{* * *}$ & $0.352^{* * *}$ & 1625 \\
\hline Migration Target-Home Damage & $99.943^{* * *}$ & $91.535^{* * *}$ & 0.337 & $0.244^{* * *}$ & $0.122^{* * *}$ & $0.237^{* * *}$ & 1682 \\
\hline Migration Target-Deaths & 10.239 & 9.998 & $5.759^{* *}$ & 0.078 & 0.078 & 0.078 & 1678 \\
\hline Migration Target-Shelter Existence & $13.111^{* *}$ & $12.987^{* *}$ & $6.515^{* *}$ & $0.089^{* *}$ & $0.041^{* *}$ & $0.089^{* *}$ & 1660 \\
\hline
\end{tabular}

Note: The table reports pairwise independence tests for the pair of variables in the first column. In addition to the Pearson ChiSquare test, we report likelihood ratio (LR), linear-by-linear association (LLA), Cramér's phi (Phi), and Cramér's V tests. The table also reports the contingency coefficient $(\mathrm{CC})$ and the number of observations $(n)$. When both variables have two categories, we report the Yates' continuity of correction in the second column instead of the Pearson Chi-Square test. ${ }^{*},{ }^{* *}$, and ${ }^{* * *}$ denote significance at $10 \%, 5 \%$, and $1 \%$, respectively.

\footnotetext{
${ }^{13}$ For the Migration Target-Deaths variable pair, the test outcome is somewhat more ambiguous, independence being rejected only in a single test (the LLA test), but for all other pairs all the tests for independence uniformly reject independence.
} 
Table 3: Pairwise test of independence between demographic, socio-economic and conflict-related variables conditional on the survey wave (year)

\begin{tabular}{|c|c|c|c|c|c|c|c|}
\hline Variable Pairs & $\begin{array}{r}\text { Pearson } \\
\text { Chi-Square } \\
\end{array}$ & LR & LLA & Phi & Cramer's V & $\mathrm{CC}$ & $n$ \\
\hline \multicolumn{8}{|c|}{ Migration Target-Province of Origin } \\
\hline Wave 1 & $123,448^{* *}$ & $135,343^{* * *}$ & 2.5 & $0,476^{* * *}$ & $0,194^{* * *}$ & $0,430^{* * *}$ & 545 \\
\hline Wave 2 & $191,546^{* * *}$ & $117,921^{\text {**** }}$ & 0.082 & $0,409^{* * *}$ & $0,183^{* * *}$ & $0,379^{* * *}$ & 1143 \\
\hline Overall & $236,095^{* * *}$ & $216,346^{* * *}$ & $24,835^{* * *}$ & $0,374^{* * *}$ & $0,153^{* * *}$ & $0,350^{* * *}$ & 1688 \\
\hline \multicolumn{8}{|c|}{ Migration Target-Gender } \\
\hline Wave 1 & $34,074^{* * *}$ & $29,935^{* * *}$ & 0.372 & $0,25^{* * *}$ & $0,25^{* * *}$ & $0,242^{* * *}$ & 547 \\
\hline Wave 2 & $69,059^{* * *}$ & $54,383^{* * * *}$ & $4,707^{* *}$ & $0,245^{* * *}$ & $0,245^{* * *}$ & $0,238^{* * *}$ & 1147 \\
\hline Overall & $34,084^{* * *}$ & $31,348^{* * * *}$ & 0.002 & $0,142^{* * *}$ & $0,142^{* * *}$ & $0,140^{* * *}$ & 1694 \\
\hline \multicolumn{8}{|c|}{ Migration Target-Education } \\
\hline Wave 1 & $54,467^{* * *}$ & $58,768^{* * *}$ & 0.849 & $0,316^{* * *}$ & $0,141^{* * *}$ & $0,301^{* * *}$ & 545 \\
\hline Wave 2 & 29.602 & 32.097 & 2.359 & 0.161 & 0.072 & 0.159 & 1138 \\
\hline Overall & $69,840^{* * *}$ & $71,597^{* * * *}$ & $26,280^{* * *}$ & $0,204^{* * *}$ & $0,091^{* *}$ & $0,200^{* * *}$ & 1683 \\
\hline \multicolumn{8}{|c|}{ Migration Target-Income } \\
\hline Wave 1 & $63,363^{* * *}$ & $64,424^{* * *}$ & $4,071^{* *}$ & $0,351^{* * * *}$ & $0,157^{* * *}$ & $0,331^{* * *}$ & 514 \\
\hline Wave 2 & $39,613^{* *}$ & $45,753^{* * * *}$ & 1.736 & $0,189^{* *}$ & $0,084^{* *}$ & $0,186^{* *}$ & 1111 \\
\hline Overall & $230,306^{* * *}$ & $207,051^{\text {**** }}$ & $78,030^{* * *}$ & $0,376^{* * *}$ & $0,168^{* * *}$ & $0,352^{* * *}$ & 1625 \\
\hline \multicolumn{8}{|c|}{ Migration Target-Home Damage } \\
\hline Wave 1 & $43,130^{* * *}$ & $41,029^{* *}$ & 0.443 & $0,281^{* * *}$ & $0,141^{* * *}$ & $0,271^{* * *}$ & 545 \\
\hline Wave 2 & $46,401^{* * *}$ & $46,247^{* * * *}$ & 0.008 & $0,202^{* * *}$ & $0,101^{* * *}$ & $0,198^{* * *}$ & 1137 \\
\hline Overall & $99,943^{* * *}$ & $91,535^{* * *}$ & 0.377 & $0,244^{* * * *}$ & $0,122^{* * *}$ & $0,237^{* * *}$ & 1682 \\
\hline \multicolumn{8}{|c|}{ Migration Target-Deaths } \\
\hline Wave 1 & 4.779 & 4.813 & 0.001 & 0.094 & 0.094 & 0.094 & 541 \\
\hline Wave 2 & $11,656^{* * *}$ & $11,036^{*}$ & $3,682^{*}$ & $0,101^{* *}$ & $0,101^{* *}$ & $0,101^{* *}$ & 1137 \\
\hline Overall & 10.239 & 9.998 & $5,759^{* *}$ & 0.078 & 0.078 & 0.078 & 1678 \\
\hline \multicolumn{8}{|c|}{ Migration Target-Shelter Existence } \\
\hline Wave 1 & $14,087^{* *}$ & $14,129^{* *}$ & 1.485 & $0,162^{* *}$ & $0,162^{* *}$ & $0,160^{* *}$ & 539 \\
\hline Wave 2 & 5.878 & 5.775 & 0.481 & 0.072 & 0.072 & 0.072 & 1121 \\
\hline Overall & $13,111^{* *}$ & $12,987^{* *}$ & $6,515^{* *}$ & 0.089 & 0.089 & 0.089 & 1660 \\
\hline \multicolumn{8}{|c|}{ Migration Plan-Province of Origin } \\
\hline Wave 1 & $43,210^{* *}$ & $42,618^{* *}$ & 0.746 & $0,130^{* *}$ & $0,092^{* *}$ & $0,129^{* *}$ & 2546 \\
\hline Wave 2 & $44,720^{* * * *}$ & $40,123^{* * * *}$ & 1.503 & $0,199^{* * *}$ & $0,141^{\text {**** }}$ & $0,195^{* * *}$ & 1131 \\
\hline Overall & $47,267^{* * * *}$ & $43,715^{* *}$ & 0.928 & $0,113^{* * *}$ & $0,080^{* * * *}$ & $0,113^{* * *}$ & 3677 \\
\hline \multicolumn{8}{|c|}{ Migration Plan-Gender } \\
\hline Wave 1 & $7,886^{* *}$ & $8,190^{* *}$ & $4,924^{* *}$ & $0,056^{* *}$ & $0,056^{* *}$ & $0,056^{* *}$ & 2552 \\
\hline Wave 2 & $14,039^{* * * *}$ & $13,112^{* * * *}$ & $9,643^{* *}$ & $0,112^{* * *}$ & $0,112^{* * *}$ & $0,112^{* * *}$ & 1110 \\
\hline Overall & 0.392 & 0.397 & 0.357 & 0.01 & 0.01 & 0.01 & 3662 \\
\hline \multicolumn{8}{|c|}{ Migration Plan-Education } \\
\hline Wave 1 & 15.586 & 15.255 & $10,435^{* * *}$ & 0.078 & 0.055 & 0.078 & 2546 \\
\hline Wave 2 & 6.801 & 7.102 & 1.375 & 0.078 & 0.055 & 0.078 & 1120 \\
\hline Overall & $25,329^{* * *}$ & $24,649^{* * * *}$ & $17,304^{* * *}$ & $0,083^{* * *}$ & $0,058^{* * *}$ & $0,083^{* * *}$ & 3666 \\
\hline \multicolumn{8}{|c|}{ Migration Plan-Income } \\
\hline Wave 1 & $19,330^{* *}$ & $20,312^{* *}$ & $3,040^{*}$ & $0,091^{* *}$ & $0,065^{* *}$ & $0,091^{* *}$ & 2315 \\
\hline Wave 2 & $19,618^{* *}$ & $18,305^{* *}$ & 1.337 & $0,133^{* *}$ & $0,094^{* *}$ & $0,132^{* *}$ & 1102 \\
\hline Overall & $26,333^{* * *}$ & $25,856^{* * *}$ & $14,838^{* * *}$ & $0,088^{* * *}$ & $0,062^{* * *}$ & $0,087^{* * *}$ & 3417 \\
\hline
\end{tabular}

Note: See notes to Table 2. 
Table 3: (continued)

\begin{tabular}{|c|c|c|c|c|c|c|c|}
\hline Variable Pairs & $\mathrm{X} 2$ & LR & LLA & Phi & Cramer's V & $\mathrm{CC}$ & $\mathrm{n}$ \\
\hline \multicolumn{8}{|c|}{ Migration Plan-Home Damage } \\
\hline Wave 1 & 12.671 & 12.717 & 0.787 & 0.071 & 0.05 & 0.071 & 2535 \\
\hline Wave 2 & 6.451 & 6.276 & 0.114 & 0.076 & 0.054 & 0.076 & 1124 \\
\hline Overall & $14,656^{*}$ & $14,359^{*}$ & 0.956 & $0,063^{*}$ & $0,045^{*}$ & $0,063^{*}$ & 3659 \\
\hline \multicolumn{8}{|c|}{ Migration Plan-Deaths } \\
\hline Wave 1 & $6,206^{* *}$ & $6,113^{* *}$ & $6,160^{* * *}$ & $0,049^{* *}$ & $0,049^{* *}$ & $0,049^{* *}$ & 2541 \\
\hline Wave 2 & 1.989 & 1.955 & 1.96 & 0.042 & 0.042 & 0.042 & 1123 \\
\hline Overall & $8,205^{* *}$ & $8,077^{* *}$ & $8,125^{* * *}$ & $0,047^{* *}$ & $0,047^{* *}$ & $0,047^{* *}$ & 3664 \\
\hline \multicolumn{8}{|c|}{ Migration Plan-Shelter Existence } \\
\hline Wave 1 & 2.538 & 2.548 & 2.38 & 0.032 & 0.032 & 0.032 & 2507 \\
\hline Wave 2 & 0.232 & 0.234 & 0.22 & 0.014 & 0.014 & 0.014 & 1110 \\
\hline Overall & 1.529 & 1.534 & 1.36 & 0.021 & 0.021 & 0.021 & 3617 \\
\hline \multicolumn{8}{|c|}{ Return Condition-Province of Origin } \\
\hline Wave 1 & $127,913^{* * * *}$ & $129,008^{* * *}$ & 2.331 & $0,224^{* * *}$ & $0,100^{* * *}$ & $0,218^{* * *}$ & 2558 \\
\hline Wave 2 & $77,389^{* * *}$ & $58,187^{*}$ & 0.879 & $0,273^{* * *}$ & $0,136^{* * *}$ & $0,263^{* * * *}$ & 1042 \\
\hline Wave 3 & $91,638^{* * *}$ & $86,440^{* * *}$ & 2.519 & $0,380^{* * * *}$ & $0,170^{* * *}$ & $0,355^{* * *}$ & 634 \\
\hline Overall & $241,287^{* * *}$ & $233,694^{* * *}$ & $12,694^{* * * *}$ & $0,239^{* * *}$ & $0,107^{* * *}$ & $0,232^{* * *}$ & 4234 \\
\hline \multicolumn{8}{|c|}{ Return Condition-Gender } \\
\hline Wave 1 & 6.276 & 6.848 & 2.281 & 0.049 & 0.049 & 0.049 & 2563 \\
\hline Wave 2 & 6.505 & 7.477 & $5,766^{* * *}$ & 0.8 & 0.8 & 0.8 & 1023 \\
\hline Wave 3 & $15,879^{* * * *}$ & $16,134^{* * *}$ & $7,987^{* * *}$ & $0,159^{* * *}$ & $0,159^{* * *}$ & $0,157^{* * *}$ & 629 \\
\hline Overall & $9,925^{*}$ & $10,470^{*}$ & $3,103^{*}$ & $0,049^{*}$ & $0,049^{*}$ & $0,048^{*}$ & 4215 \\
\hline \multicolumn{8}{|c|}{ Return Condition-Education } \\
\hline Wave 1 & $41,154^{* *}$ & $38,789^{* *}$ & 0.652 & $0,127^{* *}$ & $0,057^{* *}$ & $0,126^{* *}$ & 2557 \\
\hline Wave 2 & $45,646^{* * *}$ & $42,946^{* * *}$ & 0.727 & $0,210^{* * * *}$ & $0,105^{* * *}$ & $0,205^{* * *}$ & 1037 \\
\hline Wave 3 & 34.32 & $35,213^{*}$ & 2.546 & 0.238 & 0.106 & 0.231 & 608 \\
\hline Overall & $60,011^{* * *}$ & $57,164^{* * *}$ & 2.213 & $0,120^{* * *}$ & $0,053^{* * *}$ & $0,119^{* * *}$ & 4202 \\
\hline \multicolumn{8}{|c|}{ Return Condition-Income } \\
\hline Wave 1 & $37,690^{* *}$ & $36,805^{*}$ & 0.57 & $0,127^{* *}$ & $0,057^{* *}$ & $0,126^{* *}$ & 2324 \\
\hline Wave 2 & $38,477^{* * *}$ & 27.094 & 0.913 & $0,195^{* * *}$ & $0,097^{* * *}$ & $0,191^{* * *}$ & 1012 \\
\hline Wave 3 & 21.99 & 23.008 & $7,601^{* * *}$ & 0.189 & 0.085 & 0.186 & 614 \\
\hline Overall & $139,077^{* * *}$ & $150,961^{* * *}$ & $21,393^{* * *}$ & $0,188^{* * * *}$ & $0,084^{* * *}$ & $0,184^{* * *}$ & 3950 \\
\hline \multicolumn{8}{|c|}{ Return Condition-Home Damage } \\
\hline Wave 1 & $41,684^{* * * *}$ & $43,580^{* *}$ & 0.888 & $0,128^{* * *}$ & $0,064^{* * *}$ & $0127^{* * *}$ & 2544 \\
\hline Wave 2 & 21.707 & 22.332 & 1.757 & 0.145 & 0.072 & 0.143 & 1037 \\
\hline Wave 3 & 25.996 & 25.88 & 0.008 & 0.203 & 0.102 & 0.199 & 630 \\
\hline Overall & $76,597^{* * * *}$ & $79,998^{* * *}$ & $4,513^{* *}$ & $0,135^{* * *}$ & $0,067^{* * *}$ & $0,134^{* * *}$ & 4211 \\
\hline \multicolumn{8}{|c|}{ Return Condition-Deaths } \\
\hline Wave 1 & $13,706^{* *}$ & $13,497^{* *}$ & 1.771 & $0,073^{* *}$ & $0,073^{* *}$ & $0,073^{* *}$ & 2250 \\
\hline Wave 2 & $12,345^{* *}$ & $11,822^{* *}$ & 0.302 & $0,109^{\text {** }}$ & $0,109^{* *}$ & $0,108^{* *}$ & 1037 \\
\hline Wave 3 & $19,813^{* * *}$ & $19,855^{* * *}$ & $5,191^{* *}$ & $0,178^{* * *}$ & $0,178^{* * *}$ & $0,175^{* * *}$ & 627 \\
\hline Overall & $29,494^{* * *}$ & $28,913^{* * *}$ & $3,001^{*}$ & $0,084^{* * *}$ & $0,084^{* * *}$ & $0,083^{* * *}$ & 4214 \\
\hline \multicolumn{8}{|c|}{ Return Condition-Shelter Existence } \\
\hline Wave 1 & $13,476^{* *}$ & $13,758^{* *}$ & 0.663 & $0,073^{* *}$ & $0,073^{* *}$ & $0,073^{* *}$ & 2511 \\
\hline Wave 2 & $12,983^{* *}$ & $13,014^{* *}$ & $2,840^{*}$ & $0,113^{* *}$ & $0,113^{* *}$ & $0,112^{* *}$ & 1019 \\
\hline Overall & $26,381^{* * *}$ & $26,911^{* * *}$ & $4,560^{* *}$ & $0,086^{* * *}$ & $0,086^{* * *}$ & $0,086^{* * *}$ & 3530 \\
\hline
\end{tabular}

Note: See notes to Table 2.

As described above the data used in the analysis come from each of the three different waves of the AFAD Survey. Therefore, in order to determine whether the dependencies between the variable pairs are robust to the different survey waves, we carry out another set of independence tests, in this case for the variable pairs conditional on the survey wave, i.e., Wave 1, Wave 2, and Wave 3. These conditional dependency test results are presented in Table 3. This table shows that 
the independence tests are quite robust to survey wave and that, once again, independence is rejected for most variable pairs for all survey waves for which the relevant data exists. There are, however, some exceptions, specifically those for the following variable pairs: Migration TargetEducation, Migration Target-Deaths, Migration Plan-Education, Migration Plan-Home Damage, Migration Plan-Shelter Existence, Return Condition-Gender, and Return Condition-Home Damage. For these variables the test results vary either across survey waves or from the case in which the waves are combined, pointing out that the survey waves have some heterogeneity. ${ }^{14}$

The evidence in Tables 2 and 3 shows quite clearly that most of the possible determinants of subsequent identified in these tables are related in statistically significant ways to the migration intention measures, suggesting the use of a multivariate regression analysis. Because conflict and thus damages in the form of deaths and home destruction were inflicted on virtually all ethnic or religious groups in Syria and by no means exclusively by government and Russian forces, in many cases as a result of indiscriminate bombing and well before the time of the AFAD surveys in Turkey, we deem it fair to treat the conflict variables and even their magnitudes as exogenous, not requiring the use of any two stage analysis and specially designed instruments.

Therefore, in Table 4 we present the parameter estimates obtained from the logit model from the general model in which all covariates are included in the regression. The results also include for each explanatory variable, the standard errors and significance levels, and for each regression, some fit statistics, i.e., $\log$ likelihood $(\log L)$, the Akaike Information Criterion (AIC), and the Bayesian Information Criterion (BIC).

For the variables INCOME, EDUCATION, and RFGTIME, each of which has multiple categories representing the different levels of these variables, the results in Table 4 reveal many cases in which the parameter estimates are not statistically significant, but even so, there is usually at least one category of the variable for which the parameter estimate is statistically significant. Overall, however, with respect to income, some non-linearity seems evident. Both those with the lowest and highest incomes in Syria before leaving as refugees are more likely to respond RETURN and especially RTNASAP. At the same time, however, those who had the highest incomes back in Syria are very likely to want to migrate elsewhere (MIGRATEINT). As the level

\footnotetext{
14 Table 3 also shows that independence via the LLA test is generally not rejected when survey waves are considered separately, but that it is rejected when each of the other independence tests are used. This means that the associations between the variable pairs are nonlinear.
} 
Table 4: Logit model estimates

\begin{tabular}{|c|c|c|c|c|}
\hline \multirow[t]{2}{*}{ Independent variable } & \multicolumn{4}{|c|}{ Dependent variable } \\
\hline & RETURN & MIGRATE & RTNASAP & MIGRATEINT \\
\hline \multirow[t]{2}{*}{ FEMALE } & $0.33230^{* *}$ & 0.00060 & -0.55002 & -0.38569 \\
\hline & $(0.15630)$ & $(0.11676)$ & $(0.38819)$ & $(0.37299)$ \\
\hline \multirow[t]{2}{*}{ INCOME: 10001-20000 } & $0.32057^{* *}$ & -0.05775 & $0.88505^{* *}$ & $0.58175^{*}$ \\
\hline & $(0.13628)$ & $(0.11264)$ & $(0.34842)$ & $(0.33686)$ \\
\hline \multirow[t]{2}{*}{ INCOME: 20001-30000 } & 0.22928 & 0.15526 & $0.74672^{*}$ & 0.39362 \\
\hline & $(0.17313)$ & $(0.13571)$ & $(0.41831)$ & $(0.43097)$ \\
\hline \multirow[t]{2}{*}{ INCOME: 30001-40000 } & 0.08670 & $0.42982^{* *}$ & 0.66656 & 0.82231 \\
\hline & $(0.26670)$ & $(0.20593)$ & $(0.65585)$ & $(0.57438)$ \\
\hline \multirow[t]{2}{*}{ INCOME: 40001-50000 } & $0.57655^{*}$ & $0.41642^{* *}$ & $1.27636^{* *}$ & 0.76707 \\
\hline & $(0.30775)$ & $(0.20129)$ & $(0.51170)$ & $(0.57313)$ \\
\hline \multirow[t]{2}{*}{ INCOME: 500001+ } & 0.29771 & 0.31917 & $1.53836^{* * * *}$ & $1.57844^{* * *}$ \\
\hline & $(0.29131)$ & $(0.21105)$ & $(0.47479)$ & $(0.46070)$ \\
\hline \multirow{2}{*}{ EDUCATION: Literate } & $0.43351^{*}$ & 0.06514 & -0.22705 & -0.34010 \\
\hline & $(0.24949)$ & $(0.18620)$ & $(0.61863)$ & $(0.60798)$ \\
\hline \multirow{2}{*}{ EDUCATION: Primary school } & 0.11410 & 0.20400 & 0.42025 & 0.06011 \\
\hline & $(0.17397)$ & $(0.14547)$ & $(0.42266)$ & $(0.41711)$ \\
\hline \multirow[t]{2}{*}{ EDUCATION: Elementary school } & 0.03513 & 0.15039 & 0.16771 & -0.17036 \\
\hline & $(0.18185)$ & $(0.15330)$ & $(0.45054)$ & $(0.45556)$ \\
\hline \multirow{2}{*}{ EDUCATION: High school } & -0.08315 & $0.31714^{*}$ & 0.27072 & 0.34626 \\
\hline & $(0.20789)$ & $(0.17135)$ & $(0.48902)$ & $(0.46047)$ \\
\hline \multirow[t]{2}{*}{ EDUCATION: Bachelor/graduate } & -0.07044 & $0.29107^{*}$ & 0.53190 & 0.00187 \\
\hline & $(0.21230)$ & $(0.17268)$ & $(0.46062)$ & $(0.49191)$ \\
\hline \multirow[t]{2}{*}{ NOSHELTER } & $-0.24024^{* *}$ & 0.05654 & 0.07026 & -0.00127 \\
\hline & $(0.12210)$ & $(0.09614)$ & $(0.25514)$ & $(0.26919)$ \\
\hline \multirow[t]{2}{*}{ DAMAGE } & 0.00177 & -0.06503 & -0.19368 & 0.42508 \\
\hline & $(0.12115)$ & $(0.09735)$ & $(0.25527)$ & $(0.26677)$ \\
\hline \multirow[t]{2}{*}{ DEATH } & $-0.1928^{*}$ & 0.11506 & -0.03156 & $0.45464^{*}$ \\
\hline & $(0.11696)$ & $(0.09495)$ & $(0.25826)$ & $(0.25741)$ \\
\hline \multirow[t]{2}{*}{ RFGTIME: 13-24 months } & $-0.47363^{* * *}$ & -0.06020 & -0.42135 & $0.94296^{* * *}$ \\
\hline & $(0.13225)$ & $(0.11595)$ & $(0.36470)$ & $(0.27420)$ \\
\hline \multirow[t]{2}{*}{ RFGTIME: 25-36 months } & $-1.63955^{* * *}$ & $-0.60977^{*}$ & -0.79406 & -0.40111 \\
\hline & $(0.23240)$ & $(0.32802)$ & $(1.02226)$ & $(1.02786)$ \\
\hline RFGTIME: $37-48$ months & $\begin{array}{r}-4.67346^{* * * *} \\
(1.05746)\end{array}$ & & & \\
\hline \multirow[t]{2}{*}{ Constant } & $2.17885^{* * * *}$ & $-1.73834^{* * *}$ & $-4.50997^{* * *}$ & $-4.93668^{* * *}$ \\
\hline & $(0.18627)$ & $(0.16123)$ & $(0.48205)$ & $(0.48517)$ \\
\hline$N$ & 3367 & 3356 & 3356 & 3356 \\
\hline $\log L$ & -1135.460 & -1597.625 & -338.313 & -305.298 \\
\hline AIC & 2306.919 & 3229.249 & 710.626 & 644.596 \\
\hline BIC & 2417.111 & 3333.264 & 814.641 & 748.610 \\
\hline
\end{tabular}

Note: Table reports the maximum likelihood estimates of the logit models. Standard errors of the estimates are given in parentheses. In addition to the number of observations $(n)$, the table reports the $\log$ likelihood $(\log L)$, the Akaike Information Criterion (AIC), and the Bayesian Information Criterion (BIC). ${ }^{* * *}$, and ${ }^{* * *}$ denote significance at $10 \%, 5 \%$, and $1 \%$, respectively.

of education rises, the probability of RETURN tends to fall and the probability of MIGRATE tends to rise, but in both cases only weakly. FEMALE raises the probability of RETURN but not of 
RTNASAP. The refugees are less likely to return if they would not have access to shelter back in Syria (NOSHELTER). The relationships between damage to their home back in Syria (DAMAGE) and subsequent migration choices in direction across the four alternatives but are not statistically significant. The relation between DAMAGE in future migration choice that is closest to being significant is the positive one on MIGRATEINT. The parameter estimates of deaths in the family (DEATH) is more clear-cut; it is negatively related to RETURN and positively to MIGRATEINT. The parameter estimates for the RFGTIME variable shows that, as the time lived as refugee increases, RETURN decreases and MIGRATEINT increases.

None of the specifications in Table 4, however, included the measures for the quality of services received by the refugees in Turkey which as suggested above could also have a major bearing on the future choices of the refugees with respect to migration, RETURN, RTNASAP, MIGRATE and MIGRATEINT. To that end, therefore, we deem it also relevant to capture the impact of the type of living environment with IN-CAMP and the quality of service measures (WATER AND HYGIENE, HEALTH SERVICE AND SECURITY) on each of these future migration measures.

Following our rule of excluding variables which were previously found to have insignificant effects like education (and also income and damage in the case of RETURN), but then in columns (4) and (6) including the four new quality of service provision measures leads to the results with the full set of explanatory variables presented in Table 5 for the determinants of both RETURN and MIGRATEINT.

From columns (1), (3) and (4) of Table 5 it can be seen, as in Table 4, that women are more likely to want to return to Syria than men, but among all refugees the likelihood of returning to Syria is significantly lowered by NOSHELTER, DEATH and time as a refugee (measured by either years or months). Many others of the effects found statistically significant are consistent with the results of the general Logit model in Table 4. Note, however, that the addition of HEALTH SERVICE and SECURITY lowers the probability of both RETURN and MIGRATEINT, implying that this has the effect of raising the probability that the refugees will want to stay in Turkey. Location IN-CAMP, however has the effect of raising both RETURN and MIGRATEINT. These results imply that high quality of services provided to the refugees is likely to keep the refugees in Turkey, implying the possibility that doing well by the refugees via high quality services may well 
have the effects of extending over time the costs to Turkey and/or funding institutions for taking care of the refugees.

Table 5: Logit models selected by general to specific modelling approach

\begin{tabular}{|c|c|c|c|c|c|c|}
\hline & Model 1 & Model 2 & Model 3 & Model 4 & Model 5 & Model 6 \\
\hline Independent Variable & \multicolumn{6}{|c|}{ Dependent Variable } \\
\hline \multirow{3}{*}{ FEMALE } & RETURN & MIGRATEINT & RETURN & RETURN & MIGRATEINT & MIGRATEINT \\
\hline & $0.25448^{*}$ & & $0.27645^{* *}$ & $0.23637^{*}$ & & \\
\hline & $(0.13993)$ & & $(0.14024)$ & $(0.14126)$ & & \\
\hline \multirow[t]{2}{*}{ NOSHELTER } & $-0.24036^{* *}$ & & $-0.25052^{* *}$ & -0.00961 & & \\
\hline & $(0.11047)$ & & $(0.11057)$ & $(0.13189)$ & & \\
\hline \multirow[t]{2}{*}{ DEATH } & $-0.19362^{*}$ & $0.49813^{* *}$ & $-0.20353^{*}$ & -0.15895 & $0.49702^{* *}$ & $0.47330^{*}$ \\
\hline & (0.11089) & $(0.25217)$ & (0.11080) & $(0.11227)$ & $(0.25254)$ & $(0.25744)$ \\
\hline RFGTIME: 13-24 months & $\begin{array}{r}-0.47479^{* * * *} \\
(0.12574)\end{array}$ & & & & & \\
\hline RFGTIME: 25-36 months & $\begin{array}{r}-1.63262^{* * * *} \\
(0.21798)\end{array}$ & & & & & \\
\hline RFGTIME: $37-48$ months & $\begin{array}{r}-3.53032^{* * * * *} \\
(0.65697)\end{array}$ & & & & & \\
\hline \multirow[t]{2}{*}{ INCOME: 10001-20000 } & & 0.36602 & & & 0.46468 & 0.33669 \\
\hline & & $(0.32019)$ & & & $(0.32245)$ & $(0.33004)$ \\
\hline \multirow[t]{2}{*}{ INCOME: 20001-30000 } & & 0.14516 & & & 0.25072 & 0.23707 \\
\hline & & $(0.41610)$ & & & (0.41838) & (0.41946) \\
\hline \multirow[t]{2}{*}{ INCOME: 30001-40000 } & & 0.54581 & & & 0.64088 & 0.58670 \\
\hline & & $(0.56188)$ & & & $(0.56342)$ & $(0.56469)$ \\
\hline \multirow[t]{2}{*}{ INCOME: 40001-50000 } & & 0.56336 & & & 0.63146 & 0.61234 \\
\hline & & $(0.56197)$ & & & $(0.56340)$ & $(0.56413)$ \\
\hline \multirow[t]{2}{*}{ INCOME: 500001+ } & & $1.24851^{* * *}$ & & & $1.39028^{* * *}$ & $1.34670^{* * * *}$ \\
\hline & & $(0.43821)$ & & & $(0.44221)$ & $(0.44409)$ \\
\hline \multirow[t]{2}{*}{ DAMAGE } & & $0.43413^{*}$ & & & $0.42480^{*}$ & $0.74459^{* *}$ \\
\hline & & $(0.25170)$ & & & $(0.25184)$ & $(0.36442)$ \\
\hline \multirow[t]{2}{*}{ RFGMONTHS } & & $0.01272^{* * * *}$ & $-0.25542^{* * *}$ & $-0.25538^{* * *}$ & $0.34529^{* * * *}$ & $0.35781^{* * * *}$ \\
\hline & & $(0.00426)$ & $(0.04713)$ & $(0.04669)$ & $(0.12250)$ & $(0.12483)$ \\
\hline \multirow{2}{*}{ RFGMONTHS $^{2}$} & & & $-0.00233^{* * *}$ & $-0.00232^{* * * *}$ & $0.00402^{* * *}$ & $0.00419^{* * *}$ \\
\hline & & & $(0.00053)$ & $(0.00053)$ & $(0.00139)$ & $(0.00142)$ \\
\hline \multirow[t]{2}{*}{ IN-CAMP } & & & & $0.44918^{* *}$ & & $-0.59585^{* *}$ \\
\hline & & & & $(0.21530)$ & & $(0.28664)$ \\
\hline \multirow[t]{2}{*}{ WATER AND HYGINEE } & & & & -0.13887 & & -0.14574 \\
\hline & & & & $(0.24153)$ & & $(0.54015)$ \\
\hline \multirow[t]{2}{*}{ HEALTH SERVICE } & & & & $-0.49202^{* * *}$ & & $-0.51804^{* * *}$ \\
\hline & & & & $(0.22907)$ & & $(0.20131)$ \\
\hline \multirow[t]{2}{*}{ SECURITY } & & & & $-0.89883^{* * * *}$ & & $-0.94367^{* * *}$ \\
\hline & & & & $(0.20773)$ & & $(0.40019)$ \\
\hline \multirow[t]{2}{*}{ Constant } & $2.39805^{* * *}$ & $-5.39674^{* * *}$ & $2.58786^{* * *}$ & $2.21029^{* * * *}$ & $-5.37480^{* * *}$ & $-5.24470^{* * * *}$ \\
\hline & $(0.10382)$ & $(0.61358)$ & $(0.12719)$ & $(0.12910)$ & $(1.68520)$ & $(1.74222)$ \\
\hline$N$ & 3642 & 4090 & 3646 & 3621 & 4090 & 4064 \\
\hline $\log L$ & -1257.361 & -330.103 & -1257.869 & -1231.331 & -323.455 & -313.682 \\
\hline AIC & 2528.721 & 678.206 & 2527.737 & 2482.662 & 666.911 & 653.365 \\
\hline $\mathrm{BIC}$ & 2572.123 & 735.053 & 2564.945 & 2544.607 & 730.074 & 735.394 \\
\hline
\end{tabular}

Note: See notes to Table 4. 
Table 6: Logit models selected by general to specific modelling approach with DAMAGE interacted with Barrel-Bombing

\begin{tabular}{|c|c|c|c|c|c|c|}
\hline & Model 1 & Model 2 & Model 3 & Model 4 & Model 5 & Model 6 \\
\hline Independent Variable & \multicolumn{6}{|c|}{ Dependent Variable } \\
\hline \multirow{3}{*}{ FEMALE } & RETURN & MIGRATEINT & RETURN & RETURN & MIGRATEINT & MIGRATEINT \\
\hline & $0.26658^{*}$ & & $0.27741^{*}$ & $0.24599^{*}$ & & \\
\hline & $(0.14659)$ & & $(0.14072)$ & $(0.14701)$ & & \\
\hline \multirow[t]{2}{*}{ NOSHELTER } & $-0.26175^{* * *}$ & & $-0.27194^{* *}$ & -0.00969 & & \\
\hline & $(0.12030)$ & & $(0.12003)$ & $(0.13293)$ & & \\
\hline \multirow{2}{*}{ DEATH } & $-0.20533^{*}$ & $0.54565^{*}$ & $-0.22094^{*}$ & -0.16677 & $0.50493^{*}$ & $0.47764^{*}$ \\
\hline & $(0.11760)$ & $(0.27623)$ & $(0.12028)$ & $(0.11779)$ & $(0.25656)$ & $(0.25980)$ \\
\hline RFGTIME: 13-24 months & $\begin{array}{r}-0.49260^{* * * *} \\
(0.13046)\end{array}$ & & & & & \\
\hline RFGTIME: 25-36 months & $\begin{array}{r}-1.77072^{* * * *} \\
(0.23642)\end{array}$ & & & & & \\
\hline RFGTIME: $37-48$ months & $\begin{array}{r}-3.53488^{* * * *} \\
(0.65782)\end{array}$ & & & & & \\
\hline \multirow[t]{2}{*}{ INCOME: 10001-20000 } & & 0.38611 & & & 0.50516 & 0.35628 \\
\hline & & $(0.33777)$ & & & $(0.35054)$ & $(0.34924)$ \\
\hline \multirow{2}{*}{ INCOME: 20001-30000 } & & 0.15836 & & & 0.26558 & 0.25738 \\
\hline & & $(0.45393)$ & & & $(0.44317)$ & $(0.45540)$ \\
\hline \multirow[t]{2}{*}{ INCOME: 30001-40000 } & & 0.57709 & & & 0.68372 & 0.58927 \\
\hline & & $(0.59408)$ & & & $(0.60108)$ & $(0.56716)$ \\
\hline \multirow[t]{2}{*}{ INCOME: 40001-50000 } & & 0.57441 & & & 0.66665 & 0.62907 \\
\hline & & $(0.57299)$ & & & $(0.59480)$ & $(0.57954)$ \\
\hline \multirow{2}{*}{ INCOME: 500001+ } & & $1.26700^{* * * *}$ & & & $1.52337^{* * *}$ & $1.35311^{\text {*** }}$ \\
\hline & & $(0.44470)$ & & & $(0.48454)$ & $(0.44620)$ \\
\hline \multirow[t]{2}{*}{ DBBOMBAREA*BBOMTIME } & $0.66803^{* * *}$ & $0.83683^{* *}$ & $0.59395^{* * *}$ & $0.70057^{* * *}$ & $0.76719^{* * * *}$ & $0.83426^{* * *}$ \\
\hline & $(0.13507)$ & $(0.31391)$ & $(0.06760)$ & $(0.16390)$ & $(0.21584)$ & $(0.27401)$ \\
\hline \multirow[t]{2}{*}{ RFGMONTHS } & & $0.01323^{* * *}$ & $-0.26514^{* * *}$ & $-0.27032^{* * *}$ & $0.36544^{* * *}$ & $0.36876^{* * *}$ \\
\hline & & $(0.00443)$ & $(0.04892)$ & $(0.04942)$ & $(0.12965)$ & $(0.12865)$ \\
\hline \multirow{2}{*}{ RFGMONTHS $^{2}$} & & & $-0.00254^{* * *}$ & $-0.00253^{* * *}$ & $0.00421^{* * *}$ & $0.00437^{* * * *}$ \\
\hline & & & $(0.00058)$ & $(0.00058)$ & $(0.00146)$ & $(0.00148)$ \\
\hline \multirow[t]{2}{*}{ IN-CAMP } & & & & $0.46617^{* *}$ & & $-0.64939^{* *}$ \\
\hline & & & & $(0.22344)$ & & $(0.31239)$ \\
\hline \multirow{2}{*}{ WATER AND HYGINEE } & & & & -0.15168 & & -0.15939 \\
\hline & & & & $(0.26380)$ & & $(0.59073)$ \\
\hline \multirow[t]{2}{*}{ HEALTH SERVICE } & & & & $-0.50134^{* *}$ & & $-0.55538^{* * *}$ \\
\hline & & & & $(0.23341)$ & & $(0.21582)$ \\
\hline \multirow[t]{2}{*}{ SECURITY } & & & & $-0.98863^{* * *}$ & & $-1.03478^{* * *}$ \\
\hline & & & & $(0.22848)$ & & $(0.43883)$ \\
\hline \multirow{2}{*}{ Constant } & $2.48929^{* * *}$ & $-5.79047^{* * *}$ & $2.83513^{* * *}$ & $2.40829^{* * *}$ & $-5.52488^{* * *}$ & $-5.59347^{* * *}$ \\
\hline & $(0.10777)$ & $(0.65834)$ & $(0.13934)$ & $(0.14067)$ & $(1.73226)$ & (1.85808) \\
\hline$N$ & 3642 & 4090 & 3646 & 3621 & 4090 & 4064 \\
\hline $\log L$ & -1310.013 & -367.341 & -1317.740 & -1302.428 & -341.528 & -337.415 \\
\hline AIC & 2636.026 & 752.682 & 2649.480 & 2626.856 & 703.056 & 702.830 \\
\hline BIC & 2685.628 & 809.529 & 2692.890 & 2694.996 & 766.219 & 791.169 \\
\hline
\end{tabular}

Note: See notes to Table 4.

As noted above, based on the aforementioned papers of Tyner (2016) and Fabbe et al (2017), one might like to see how much the results would change if instead of DAMAGE we used damage sustained from barrel bombing. To that end, we construct a term representing the interaction between homes damaged and migration from those locations and time periods identified by Fabbe et al (2017) where and when barrel bombs were used ${ }^{15}$. We label this new variable D*BBOMBAREA*BBOMBTIME and include it (instead of DAMAGE) in all columns

15 These were primarily Aleppo, Hama, Homs and Idlib and between January 2014 and May 2015. 
of Table 6 but otherwise with the same specifications of Table 5. As the reader can easily see by comparing these two tables, the newly constructed BarrelBomb variable is now more strongly related to the MIGRATEINT variable in Table 6 than was DAMAGE in Table 5. It is also now positively and significantly related to RETURN. Nevertheless, in all cases its coefficient on MIGRATEINT is larger in magnitude than that on RETURN, especially when (as deemed desirable) we include also the four service quality measures. The main thing to take from this table, however, is the robustness of all the other results, namely, the positive relationships between Female and RETURN and negative ones between RETURN and NOSHELTER, DEATH and Refugee Time, and the positive relationships between MIGRATEINT and DEATH, INCOME, and Refugee Time, and the negative relation between both RETURN and MIGRATEINT with the quality of services to the refugees in Turkey. Because of the aforementioned comment that this measure could be picking up long time mutual familiarity (along with this distinctive form of bombing), this DAMAGE-barrel-bombing interacted variable is omitted from subsequent analyses.

Considering the different ways in which the magnitudes of the different explanatory variables are measured, to make their effects more comparable to one another, in Table 7 we present estimates of the predictive margins (that adjust the probabilities for the distribution of covariates) for each of the migration type probabilities for the more fully specified models (akin to those in Table 4). Then in Table 8 we do the same for the more carefully selected models (akin to those of Table 5 that also include HEALTH, SERVICE and SECURITY. Predictive margins are calculated at given values of the variable and using the sample values of all other values to calculate the responses (predictions) for between 1 and 2 years. As can be seen, the signs and significance of these match those of the coefficient estimates in Tables 4 and 5, though the magnitudes are often quite different. 
Table 7: Estimates of predictive margins

\begin{tabular}{|c|c|c|c|c|}
\hline \multirow[t]{2}{*}{ Independent Variable } & \multicolumn{4}{|c|}{ Dependent Variable } \\
\hline & RETURN & MIGRATE & RTNASAP & MIGRATEINT \\
\hline \multirow[t]{2}{*}{ MALE } & $0.88021^{* * *}$ & $0.18562^{* * *}$ & $0.02345^{* * *}$ & $0.02059^{* * * *}$ \\
\hline & $(0.00612)$ & $(0.00749)$ & $(0.00289)$ & $(0.00272)$ \\
\hline \multirow[t]{2}{*}{ FEMALE } & $0.90975^{* * *}$ & $0.18571^{* * *}$ & $0.01371^{* * *}$ & $0.01415^{* * *}$ \\
\hline & $(0.01114)$ & $(0.01563)$ & $(0.00490)$ & $(0.00475)$ \\
\hline \multirow[t]{2}{*}{ INCOME: 0-10000 } & $0.86748^{* * * *}$ & $0.17604^{* * * *}$ & $0.01081^{* * * *}$ & $0.01226^{* * * *}$ \\
\hline & $(0.00971)$ & $(0.01137)$ & $(0.00314)$ & $(0.00310)$ \\
\hline \multirow[t]{2}{*}{ INCOME: 10001-20000 } & $0.89887^{* * *}$ & $0.16785^{* * *}$ & $0.02576^{* * *}$ & $0.02164^{* * * *}$ \\
\hline & $(0.00877)$ & $(0.01093)$ & $(0.00454)$ & $(0.00440)$ \\
\hline \multirow[t]{2}{*}{ INCOME: 20001-30000 } & $0.89068^{* * *}$ & $0.19961^{* * *}$ & $0.02252^{* * *}$ & $0.01802^{* * * *}$ \\
\hline & $(0.01365)$ & $(0.01738)$ & $(0.00645)$ & $(0.00597)$ \\
\hline \multirow{2}{*}{ INCOME: 30001-40000 } & $0.87671^{* * *}$ & $0.24688^{* * *}$ & $0.02082^{*}$ & $0.02729^{* * *}$ \\
\hline & $(0.02596)$ & $(0.03522)$ & $(0.01191)$ & $(0.01346)$ \\
\hline \multirow[t]{2}{*}{ INCOME: 40001-50000 } & $0.91899^{* * *}$ & $0.24441^{* * *}$ & $0.03758^{* *}$ & $0.02588^{* * *}$ \\
\hline & $(0.02086)$ & $(0.03399)$ & $(0.01504)$ & $(0.01272)$ \\
\hline \multirow[t]{2}{*}{ INCOME: $500001+$} & $0.89687^{* * *}$ & $0.22697^{* * *}$ & $0.04823^{* * *}$ & $0.05576^{* * * *}$ \\
\hline & $(0.02435)$ & $(0.03401)$ & $(0.01683)$ & $(0.01926)$ \\
\hline \multirow[t]{2}{*}{ EDUCATION: Illiterate } & $0.88041^{* * *}$ & $0.16106^{* * *}$ & $0.01681^{* * *}$ & $0.01914^{* * *}$ \\
\hline & $(0.01371)$ & $(0.01579)$ & $(0.00596)$ & $(0.00639)$ \\
\hline \multirow{2}{*}{ EDUCATION: Literate } & $0.91747^{* * *}$ & $0.17001^{* * *}$ & $0.01345^{* *}$ & $0.01374^{* * *}$ \\
\hline & $(0.01518)$ & $(0.02064)$ & $(0.00669)$ & $(0.00683)$ \\
\hline \multirow[t]{2}{*}{ EDUCATION: Primary school } & $0.89138^{* * *}$ & $0.19038^{* * *}$ & $0.02530^{* * *}$ & $0.02029^{* * *}$ \\
\hline & $(0.00986)$ & $(0.01316)$ & $(0.00534)$ & $(0.00462)$ \\
\hline \multirow{2}{*}{ EDUCATION: Elementary school } & $0.88389^{* * * *}$ & $0.18230^{* * *}$ & $0.01980^{* * *}$ & $0.01622^{* * * *}$ \\
\hline & $(0.01152)$ & $(0.01432)$ & $(0.00507)$ & $(0.00464)$ \\
\hline \multirow[t]{2}{*}{ EDUCATION: High school } & $0.87183^{* * *}$ & $0.20832^{* * *}$ & $0.02188^{* * *}$ & $0.02674^{* * *}$ \\
\hline & $(0.01634)$ & $(0.02004)$ & $(0.00687)$ & $(0.00765)$ \\
\hline \multirow[t]{2}{*}{ EDUCATION: Bachelor/graduate } & $0.87318^{* * * *}$ & $0.20408^{* * *}$ & $0.02818^{* * *}$ & $0.01918^{* * *}$ \\
\hline & $(0.01675)$ & $(0.01995)$ & $(0.00752)$ & $(0.00640)$ \\
\hline \multirow[t]{2}{*}{ SHELTER: Yes } & $0.89966^{* * *}$ & $0.18054^{* * *}$ & $0.02091^{* * *}$ & $0.01938^{* * *}$ \\
\hline & $(0.00827)$ & $(0.01083)$ & $(0.00388)$ & $(0.00373)$ \\
\hline \multirow[t]{2}{*}{ SHELTER: No } & $0.87705^{* * *}$ & $0.18899^{* * *}$ & $0.02238^{* * *}$ & $0.01936^{* * *}$ \\
\hline & $(0.00725)$ & $(0.00885)$ & $(0.00344)$ & $(0.00321)$ \\
\hline \multirow[t]{2}{*}{ DAMAGE: No } & $0.88584^{* * *}$ & $0.18923^{* * *}$ & $0.02446^{* * *}$ & $0.01635^{* * *}$ \\
\hline & $(0.00916)$ & $(0.00865)$ & $(0.00462)$ & $(0.00277)$ \\
\hline \multirow[t]{2}{*}{ DAMAGE: Yes } & $0.88601^{* * *}$ & $0.17952^{* * *}$ & $0.02027^{* * *}$ & $0.02468^{* * *}$ \\
\hline & $(0.00679)$ & $(0.01119)$ & $(0.00306)$ & $(0.00460)$ \\
\hline \multirow[t]{2}{*}{ DEATH: No } & $0.89211^{* * *}$ & $0.18001^{* * *}$ & $0.02197^{* * *}$ & $0.01640^{* * *}$ \\
\hline & $(0.00636)$ & $(0.00805)$ & $(0.00307)$ & $(0.00267)$ \\
\hline \multirow[t]{2}{*}{ DEATH: Yes } & $0.87314^{* * *}$ & $0.19749^{* * *}$ & $0.02130^{* * * *}$ & $0.02548^{* * *}$ \\
\hline & $(0.00987)$ & $(0.01213)$ & $(0.00441)$ & $(0.00477)$ \\
\hline RFGTIME: $1-12$ months & $0.90555^{* * *}$ & $0.18959^{* * *}$ & $0.02347^{* * *}$ & $0.01541^{* * *}$ \\
\hline & $(0.00577)$ & $(0.00770)$ & $(0.00292)$ & $(0.00239)$ \\
\hline RFGTIME: 13-24 months & $0.85703^{* * *}$ & $0.18057^{* * *}$ & $0.01557^{* * *}$ & $0.03826^{* * *}$ \\
\hline & $(0.01362)$ & $(0.01521)$ & $(0.00518)$ & $(0.00797)$ \\
\hline RFGTIME: 25-36 months & $0.65517^{* * * *}$ & $0.11315^{* * *}$ & 0.01079 & 0.01039 \\
\hline & $(0.04910)$ & $(0.03233)$ & $(0.01078)$ & $(0.01039)$ \\
\hline RFGTIME: $37-48$ months & 0.08781 & & & \\
\hline & $(0.08383)$ & & & \\
\hline
\end{tabular}

Note: Table reports the estimates of the predictive margins. Standard errors of the estimates are given in parentheses, which are estimated using robust method. 
Table 8: Estimates of predictive margins for logit models selected by general to specific modelling approach

\begin{tabular}{|c|c|c|c|c|c|c|}
\hline & Model 1 & Model 2 & Model 3 & Model 4 & Model 5 & Model 6 \\
\hline Independent Variable & \multicolumn{6}{|c|}{ Dependent Variable } \\
\hline & RETURN & MIGRATEINT & RETURN & RETURN & MIGRATEINT & MIGRATEINT \\
\hline MALE & $\begin{array}{r}0.87909^{* * * *} \\
(0.00593)\end{array}$ & & $\begin{array}{r}0.87880^{* * * *} \\
(0.00593)\end{array}$ & $\begin{array}{r}0.87993^{* * *} \\
(0.00589)\end{array}$ & & \\
\hline FEMALE & $\begin{array}{r}0.90277^{* * * *} \\
(0.01075)\end{array}$ & & $\begin{array}{r}0.90435^{* * *} \\
(0.01060)\end{array}$ & $\begin{array}{r}0.90174^{* * *} \\
(0.01083)\end{array}$ & & \\
\hline SHELTER: Yes & $\begin{array}{r}0.89781^{* * * *} \\
(0.00780)\end{array}$ & & $\begin{array}{r}0.89847^{* * * *} \\
(0.00776)\end{array}$ & $\begin{array}{r}0.88488^{* * * *} \\
(0.00966)\end{array}$ & & \\
\hline SHELTER: No & $\begin{array}{r}0.87459^{* * * *} \\
(0.00695)\end{array}$ & & $\begin{array}{r}0.87433^{* * *} \\
(0.00695)\end{array}$ & $\begin{array}{r}0.88395^{* * * *} \\
(0.00697)\end{array}$ & & \\
\hline DEATH: No & $\begin{array}{r}0.89012^{* * * *} \\
(0.00617)\end{array}$ & $\begin{array}{r}0.01340^{* * *} \\
(0.00219)\end{array}$ & $\begin{array}{r}0.89055^{* * * *} \\
(0.00615)\end{array}$ & $\begin{array}{r}0.88944^{* * * *} \\
(0.00621)\end{array}$ & $\begin{array}{r}0.01341^{* * *} \\
(0.00219)\end{array}$ & $\begin{array}{r}0.01320^{* * * *} \\
(0.00218)\end{array}$ \\
\hline DEATH: Yes & $\begin{array}{r}0.87056^{* * * *} \\
(0.00966)\end{array}$ & $\begin{array}{r}0.02182^{* * * *} \\
(0.00402)\end{array}$ & $\begin{array}{r}0.86999^{* * *} \\
(0.00968)\end{array}$ & $\begin{array}{r}0.87367^{* * * *} \\
(0.00947)\end{array}$ & $\begin{array}{r}0.02179 * * * \\
(0.00400)\end{array}$ & $\begin{array}{r}0.02095^{* * * *} \\
(0.00393)\end{array}$ \\
\hline $\begin{array}{l}\text { RFGTIME: } 1-12 \\
\text { months }\end{array}$ & $\begin{array}{r}0.90299^{* * * *} \\
(0.00554)\end{array}$ & & & & & \\
\hline $\begin{array}{l}\text { RFGTIME: } 13-24 \\
\text { months }\end{array}$ & $\begin{array}{r}0.85293^{* * * *} \\
(0.01356)\end{array}$ & & & & & \\
\hline $\begin{array}{l}\text { RFGTIME: } 25-36 \\
\text { months }\end{array}$ & $\begin{array}{r}0.64717^{* * *} \\
(0.04727)\end{array}$ & & & & & \\
\hline $\begin{array}{l}\text { RFGTIME: } 37-48 \\
\text { months }\end{array}$ & $\begin{array}{l}0.21810^{* *} \\
(0.11087)\end{array}$ & & & & & \\
\hline INCOME: 0-10000 & & $\begin{array}{r}0.01187^{* * *} \\
(0.00286)\end{array}$ & & & $\begin{array}{r}0.01115^{* * *} \\
(0.00270)\end{array}$ & $\begin{array}{r}0.01146^{\text {*** }} \\
(0.00278)\end{array}$ \\
\hline $\begin{array}{l}\text { INCOME: } 10001- \\
20000\end{array}$ & & $\begin{array}{r}0.01702^{* * * *} \\
(000344)\end{array}$ & & & $\begin{array}{r}0.01759^{* * *} \\
(0.00356)\end{array}$ & $\begin{array}{r}0.01594^{* * * *} \\
(0.00338)\end{array}$ \\
\hline INCOME: 20001- & & $0.01370^{* * * *}$ & & & $0.01427^{* * *}$ & $0.01446^{* * *}$ \\
\hline 30000 & & $(0.00453)$ & & & $(0.00472)$ & $(0.00479)$ \\
\hline INCOME: 30001- & & $0.02029^{* *}$ & & & $0.02089^{* *}$ & $0.02035^{* *}$ \\
\hline 40000 & & $(0.01004)$ & & & $(0.01032)$ & $(0.01005)$ \\
\hline INCOME: 40001- & & $0.02064^{* *}$ & & & $0.02070^{* *}$ & $0.02086^{* *}$ \\
\hline 50000 & & $(0.01020)$ & & & $(0.01021)$ & $(0.01028)$ \\
\hline INCOME: 500001+ & & $\begin{array}{r}0.04005^{* * * *} \\
(0.01388)\end{array}$ & & & $\begin{array}{r}0.04293^{* * * *} \\
(0.01483)\end{array}$ & $\begin{array}{r}0.04220^{* * * *} \\
(0.01460)\end{array}$ \\
\hline DAMAGE: No & & $\begin{array}{r}0.01360^{* * * *} \\
(0.00225)\end{array}$ & & & $\begin{array}{r}0.02065^{* * * *} \\
(0.00373)\end{array}$ & \\
\hline DAMAGE: Yes & & $\begin{array}{r}0.02079^{* * * *} \\
(0.00376)\end{array}$ & & & $\begin{array}{r}0.01365^{* * * *} \\
(0.00226)\end{array}$ & \\
\hline IN-CAMP: Yes & & & & $\begin{array}{r}0.91828^{* * * *} \\
(0.01139)\end{array}$ & & $\begin{array}{r}0.01041^{\text {**** }} \\
(0.00624)\end{array}$ \\
\hline IN-CAMP: No & & & & $\begin{array}{r}0.88896^{* * * *} \\
(0.01441)\end{array}$ & & $\begin{array}{r}0.02620^{* * * *} \\
(0.00313)\end{array}$ \\
\hline
\end{tabular}

Note: See notes to Table 6.

It is often of interest to compare the effect of covariates in terms of their partial derivatives. For this purpose, we use average marginal effects, which provide a unified and intuitive way of describing relationships estimated with logistic regression models. Average marginal effects are the partial derivatives of the logistic function with respect to a covariate of interest. If that covariate is continuous, it measures the instantaneous rate of change in the predicted probabilities. For categorical variables, however, the average marginal effect measures the change in the predicted 
probability when the covariate is switched to the category of interest. Analogous to the predictive margins, other covariates take their sample values and they all change in the response probabilities averaged over all the sample points to obtain the average marginal effect. We then go on to estimate the standard errors of the predictive margins and average marginal effects using a robust estimation method that treats non-fixed covariates as being sampled, thereby allowing for heteroscedasticity or other violations of distributional assumptions and allows for correlation among the observations.

For example, consistent with the increasingly negative effects of RFGTIME on RETURN in Table 4, it has decreasingly positive effects on RETURN in both Table 7 and column (1) of Table 8. The same pattern is apparent for its influence on MIGRATE and RTNASAP in columns (2) and (3) of Table 7. Its impact on MIGRATEINT in Table 7, however, is somewhat less clear. Likewise, the same pattern of women being more likely to return, but not to migrate internationally, is evident in Table 7 as in the earlier tables. So too the effects of NOSHELTER, DEATH and EDUCATION on the different dependent variables in Table 7 are similar to what they were in the previous tables. Yet, while IN-CAMP has the same positive effect on RETURN in Table 7 as in Table 5, it has a positive effect (rather than the negative effect it had in Table 5) on MIGRATEINT. Since the quality of service measures are treated as continuous variables, these cannot be included in the estimates of predictive margins in Tables 7 and 8.

The predictive margin results given in Table 7 for the full models and in Table 8 for the reduced models reveal strikingly high probabilities of RETURN for individuals irrespective of their individual and conflict characteristics for those with no more than one year as a refugee in Turkey. Yet, as that RFGTIME rises, the probability of RETURN (from the predictive margins) declines sharply to 0.857 for between 1 and 2 years, to 0.655 for someone between two and three years and to a point estimate of 0.088 for someone with over 3 years as a refugee. For MIGRATE most predictive margins are concentrated between 0.18 and 0.24 , for RTNASAP most are between 0.02 and 0.04 and for MIGRATEINT, between 0.016 and 0.025 . With a very few exceptions, all these predictive margins are significant at the $1 \%$ level.

Then we turn to the results obtained for the average marginal effects calculated as described above. Estimates of the average marginal effects further strengthen the logit model parameter estimates and their predictive margins. The estimates of the average marginal effects of all the same explanatory variables as in the full model of Table 7 (with the exception of one of the pairs in GENDER, NOSHELTER and DAMAGE) are presented in Table 9. As before, notice that it is 
only at the extreme lows and highs of the education and income variables where the coefficients for these variables are statistically significant.

Table 9: Estimates of average marginal effects

\begin{tabular}{|c|c|c|c|c|}
\hline \multirow[t]{2}{*}{ Independent Variable } & \multicolumn{4}{|c|}{ Dependent Variable } \\
\hline & RETURN & MIGRATE & RTNASAP & MIGRATEINT \\
\hline \multirow[t]{2}{*}{ FEMALE } & $0.02955^{* *}$ & 0.00009 & $-0.00974^{*}$ & -0.00644 \\
\hline & $(0.01282)$ & $(0.01752)$ & $(0.00575)$ & $(0.00553)$ \\
\hline \multirow[t]{2}{*}{ INCOME: 10001-20000 } & $0.03139^{* *}$ & -0.00819 & $0.01495^{* * *}$ & $0.00938^{*}$ \\
\hline & $(0.01328)$ & $(0.01598)$ & $(0.00557)$ & $(0.00545)$ \\
\hline \multirow[t]{2}{*}{ INCOME: 20001-30000 } & 0.02320 & 0.02357 & 0.01170 & 0.00576 \\
\hline & $(0.01693)$ & $(0.02094)$ & $(0.00721)$ & $(0.00679)$ \\
\hline \multirow[t]{2}{*}{ INCOME: 30001-40000 } & 0.00923 & $0.07084^{*}$ & 0.01001 & 0.01503 \\
\hline & $(0.02771)$ & $(0.03702)$ & $(0.01233)$ & $(0.01382)$ \\
\hline \multirow{2}{*}{ INCOME: 40001-50000 } & $0.05151^{* * *}$ & $0.06837^{*}$ & $0.02676^{*}$ & 0.01362 \\
\hline & $(0.02305)$ & $(0.03590)$ & $(0.01538)$ & $(0.01312)$ \\
\hline \multirow[t]{2}{*}{ INCOME: 500001+ } & 0.02940 & 0.05093 & $0.03741^{* * *}$ & $0.04350^{* * *}$ \\
\hline & $(0.02637)$ & $(0.03603)$ & $(0.01717)$ & $(0.01959)$ \\
\hline \multirow[t]{2}{*}{ EDUCATION: Literate } & $0.03706^{*}$ & 0.00895 & -0.00335 & -0.00540 \\
\hline & $(0.02028)$ & $(0.02571)$ & $(0.00890)$ & $(0.00926)$ \\
\hline \multirow{2}{*}{ EDUCATION: Primary school } & 0.01096 & 0.02933 & 0.00849 & 0.00115 \\
\hline & $(0.01689)$ & $(0.02055)$ & $(0.00799)$ & $(0.00789)$ \\
\hline \multirow[t]{2}{*}{ EDUCATION: Elementary school } & 0.00347 & 0.02125 & 0.00299 & -0.00292 \\
\hline & $(0.01802)$ & $(0.02149)$ & $(0.00787)$ & $(0.00795)$ \\
\hline \multirow[t]{2}{*}{ EDUCATION: High school } & -0.00858 & $0.04727^{*}$ & 0.00508 & 0.00759 \\
\hline & $(0.02154)$ & $(0.02578)$ & $(0.00916)$ & $(0.01008)$ \\
\hline \multirow[t]{2}{*}{ EDUCATION: Bachelor/graduate } & -0.00724 & $0.04303^{*}$ & 0.01137 & 0.00003 \\
\hline & $(0.02190)$ & $(0.02576)$ & $(0.00969)$ & $(0.00914)$ \\
\hline \multirow[t]{2}{*}{ NOSHELTER } & $-0.02260^{* * *}$ & 0.00845 & 0.00147 & -0.00002 \\
\hline & $(0.01125)$ & $(0.01432)$ & $(0.00533)$ & $(0.00505)$ \\
\hline \multirow[t]{2}{*}{ DAMAGE } & 0.00017 & -0.00971 & -0.00419 & 0.00833 \\
\hline & $(0.01164)$ & $(0.01445)$ & $(0.00566)$ & $(0.00548)$ \\
\hline \multirow[t]{2}{*}{ DEATH } & -0.01897 & 0.01748 & -0.00066 & $0.00907^{*}$ \\
\hline & $(0.01178)$ & $(0.01460)$ & $(0.00539)$ & $(0.00548)$ \\
\hline \multirow[t]{2}{*}{ RFGTIME: 13-24 months } & $-0.04852^{* * *}$ & -0.00902 & -0.00790 & $0.02285^{* * *}$ \\
\hline & $(0.01490)$ & $(0.01717)$ & $(0.00598)$ & $(0.00836)$ \\
\hline \multirow[t]{2}{*}{ RFGTIME: 25-36 months } & $-0.25039^{* * *}$ & $-0.07644^{* * *}$ & -0.01267 & -0.00502 \\
\hline & $(0.04951)$ & $(0.03329)$ & $(0.01119)$ & $(0.01067)$ \\
\hline \multirow[t]{2}{*}{ RFGTIME: $37-48$ months } & $-0.81774^{* * *}$ & $0.00000^{* * * *}$ & $0.00000^{* * * *}$ & $0.00000^{* * *}$ \\
\hline & $(0.08403)$ & $(0.00000)$ & $(0.00000)$ & $(0.00000)$ \\
\hline
\end{tabular}

Note: Table reports the estimates of the average marginal effects. Standard errors of the estimates are given in parentheses, which are estimated using robust method. 
Table 10: Estimates of average marginal effects for logit models selected by general to specific modelling approach

\begin{tabular}{|c|c|c|c|c|c|c|}
\hline & Model 1 & Model 2 & Model 3 & Model 4 & Model 5 & Model 6 \\
\hline Independent Variable & \multicolumn{6}{|c|}{ Dependent Variable } \\
\hline & RETURN & MIGRATEINT & RETURN & RETURN & MIGRATEINT & MIGRATEINT \\
\hline FEMALE & $\begin{array}{r}0.02368^{*} \\
(0.01227)\end{array}$ & & $\begin{array}{l}0.02555^{* *} \\
(0.01215)\end{array}$ & $\begin{array}{c}0.02181^{*} \\
(0.01235)\end{array}$ & & \\
\hline NOSHELTER & $\begin{array}{r}-0.02322^{* * *} \\
(0.01046)\end{array}$ & & $\begin{array}{r}-0.02414^{* * *} \\
(0.01043)\end{array}$ & $\begin{array}{r}-0.00093 \\
(0.01280)\end{array}$ & & \\
\hline DEATH & $\begin{array}{l}-0.01956^{*} \\
(0.01148)\end{array}$ & $\begin{array}{r}0.00842^{*} \\
(0.00458)\end{array}$ & $\begin{array}{l}-0.02056^{*} \\
(0.01148)\end{array}$ & $\begin{array}{r}-0.01577 \\
(0.01136)\end{array}$ & $\begin{array}{c}0.00837^{*} \\
(0.00457)\end{array}$ & $\begin{array}{r}0.00774^{*} \\
(0.00451)\end{array}$ \\
\hline $\begin{array}{l}\text { RFGTIME: } 13-24 \\
\text { months }\end{array}$ & $\begin{array}{r}-0.05006^{* * * *} \\
(0.01465)\end{array}$ & & & & & \\
\hline $\begin{array}{l}\text { RFGTIME: } 25-36 \\
\text { months }\end{array}$ & $\begin{array}{r}-0.25583^{* * * *} \\
(0.04760)\end{array}$ & & & & & \\
\hline $\begin{array}{l}\text { RFGTIME: } 37-48 \\
\text { months }\end{array}$ & $\begin{array}{r}-0.68490^{* * *} \\
(0.11101)\end{array}$ & & & & & \\
\hline INCOME: 10001- & & 0.00515 & & & 0.00645 & 0.00449 \\
\hline 20000 & & $(0.00448)$ & & & $(0.00448)$ & $(0.00440)$ \\
\hline INCOME: 20001- & & 0.00183 & & & 0.00312 & 0.00300 \\
\hline 30000 & & $(0.00537)$ & & & $(0.00545)$ & $(0.00555)$ \\
\hline INCOME: 30001- & & 0.00842 & & & 0.00974 & 0.00889 \\
\hline 40000 & & $(0.01043)$ & & & $(0.01066)$ & $(0.01043)$ \\
\hline INCOME: 40001- & & 0.00877 & & & 0.00955 & 0.00940 \\
\hline 50000 & & $(0.01060)$ & & & $(0.01056)$ & $(0.01065)$ \\
\hline INCOME: 500001+ & & $\begin{array}{l}0.02818^{* * *} \\
(0.01418)\end{array}$ & & & $\begin{array}{l}0.03178^{* *} \\
(0.01509)\end{array}$ & $\begin{array}{l}0.03074^{* *} \\
(0.01489)\end{array}$ \\
\hline DAMAGE & & $\begin{array}{r}0.00720 \\
(0.00440)\end{array}$ & & & $\begin{array}{r}0.00701 \\
(0.00437)\end{array}$ & $\begin{array}{r}0.03377^{* * * *} \\
(0.01045)\end{array}$ \\
\hline RFGMONTHS & & $\begin{array}{l}0.00020^{* * *} \\
(0.00008)\end{array}$ & $\begin{array}{r}-0.00257^{* * * *} \\
(0.00093)\end{array}$ & $\begin{array}{r}-0.00258^{* * * *} \\
(0.00092)\end{array}$ & $\begin{array}{r}0.00071^{* * *} \\
(0.00027)\end{array}$ & $\begin{array}{c}0.00073^{* * * *} \\
(0.00026)\end{array}$ \\
\hline IN-CAMP & & & & $\begin{array}{l}0.03478^{* *} \\
(0.01580)\end{array}$ & & $\begin{array}{r}-0.04382^{* * * *} \\
(0.01465)\end{array}$ \\
\hline WATER AND & & & & -0.00946 & & $-0.01213^{* * * *}$ \\
\hline HYGINEE & & & & $(0.01637)$ & & $(0.00517)$ \\
\hline HEALTH SERVICE & & & & $\begin{array}{r}-0.03878^{* * *} \\
(0.01796)\end{array}$ & & $\begin{array}{r}-0.03668^{* * *} \\
(0.01635)\end{array}$ \\
\hline SECURITY & & & & $\begin{array}{r}-0.08362^{* * * *} \\
(0.01678)\end{array}$ & & $\begin{array}{r}-0.08255^{* * * *} \\
(0.01390)\end{array}$ \\
\hline
\end{tabular}

Note: See notes to Table 8.

Similarly, Table 10 presents the estimates of the average marginal effects for RETURN and MIGRATEINT according to roughly the same restricted specifications for the predictive margin estimates presented in Table 8. The specifications of Model 1 for RETURN in the two tables are identical, utilizing the four different dummy variables for different intervals of time as a refugee in Turkey. Yet, to reduce the number of explanatory variables in the specifications, in the remaining columns of Table 10, refugee time in Turkey is captured by RFGMONTHS. The pattern of its effect, however, remains the same, positive on MIGRATEINT in models (2), (5) and (6) but negative on RETURN in Models (3) and (4). Focusing once again on the intervening influence of 
location and service provision in Turkey, notice that the impact of IN-CAMP is positive on RETURN but negative on MIGRATEINT, but the effects of both HEALTH SERVICE and SECURITY are negative on both these variables as indicated in Models (4) and (6).

The results presented in Tables 4-10 do show that at least some of the results are quite weak and fairly sensitive to the differences in specifications used. For reasons given above, where there are such differences, we believe that the results based on the more specific models, that mitigate estimation biases resulting from the interdependencies among the different explanatory variables and which are based on averaged marginal effects such as in Table 10, are the more reliable ones. By relating these results back to our hypotheses H1-H3 identified at the end of Section III, therefore, we feel that the results provide positive support for almost all these hypotheses.

In particular, consistent with H1, both DEATH and NOSHELTER are negatively related to RETURN, and DEATH (but not NOSHELTER) is positively related to MIGRATEINT. The variable capturing somewhat less severe effects of violence DAMAGE is positively related to MIGRATEINT but not to either RETURN or RTNASAP. As in H2a, females are more likely to choose RETURN but, on the other hand, they are less inclined to respond RTNASAP (implying that they may not want to return until they can feel confident that it would be very safe to do so). $\mathrm{H} 2 \mathrm{~b}$ with respect to the impacts of income and education are only partly supported. INCOME is positively related to MIGRATE and MIGRATEINT, but is not significantly related to RETURN and related weakly in a U-shaped way to RTNASAP. In the case of EDUCATION, its only significant relation is with MIGRATE but not with MIGRATEINT, implying that it raises the desire to migrate to larger cities within Turkey but not internationally. One of the most strongly supported hypotheses is H2c in that RFGTIME is strongly negatively related to RETURN, but positively related to MIGRATEINT. Finally, there is also strong support for $\mathrm{H} 3$ in that the higher the quality rating of the services received by refugees, HEALTH SERVICE and SECURITY and to a lesser extent WATER AND HYGIENE, the less likely they are to choose either RETURN or MIGRATEINT, implying that they are inclined to want to remain in Turkey.

To highlight the aforementioned finding concerning the impact of time as a refugee on the decisions to RETURN and MIGRATEINT, we make use of the Models 4 and 5, respectively of Table 5 which use the most specific measures of time as a refugee, RFGMONTHS and RFGMONTHS $^{2}$ and the preferred more restricted versions of the model. The choices of Models 4 and 5 among the alternative versions of the model in Table 5 are based on the fact that these 
specifications minimize their respective BIC criteria. Figure 3 uses these results to plot the predictive margin estimates of return probability (RETURN) for time lived as a refugee in Turkey and Figure 4 does the same for MIGRATEINT. Figure 3 shows that the return probabilities fall from 0.90 to 0.20 in less than 48 months, implying that as the Syrian war is now entering its seventh year, the probability of those refugees outside Syria of returning to Syria is now less than $20 \%$. Figure 4 shows that time as a refugee also raises the probability of international re-migration decisions quite significantly. 60 months after leaving Syria, the probability of international migration (which has been increasing continuously), will have doubled relative to what it was at the beginning. Also, as can be seen by comparing the coefficients of RFGMONTHS in columns (3) and (4) for RETURN, and in columns (5) and (6) for MIGRATEINT in Table 10, the corresponding estimates are quite robust to the inclusion of the intervening variables IN-CAMP and the quality of services provided to the refugees.

Figure 3: Predictive margin estimates of return probability for months passed after leaving

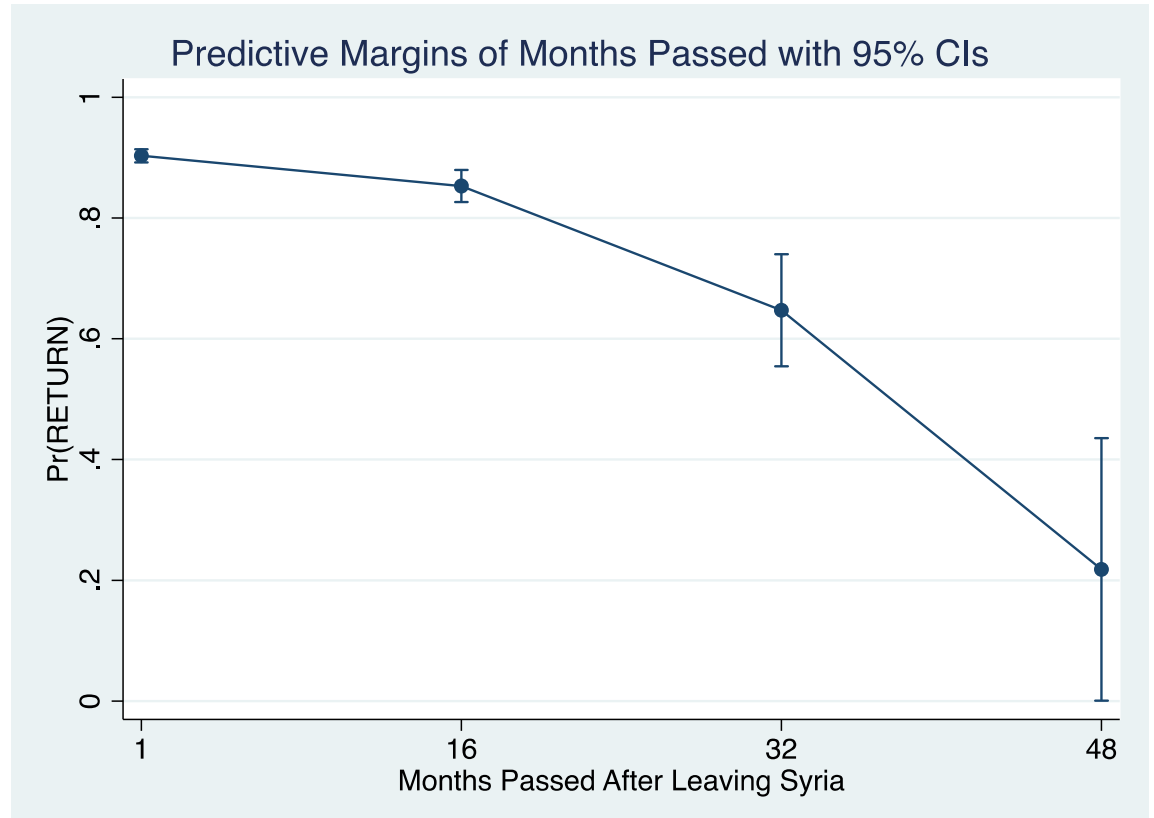

Note: these simulations are based on the estimates reported in column (4) of Table 5. 
Figure 4: Predictive margin estimates of international migration probability for months passed after leaving Syria

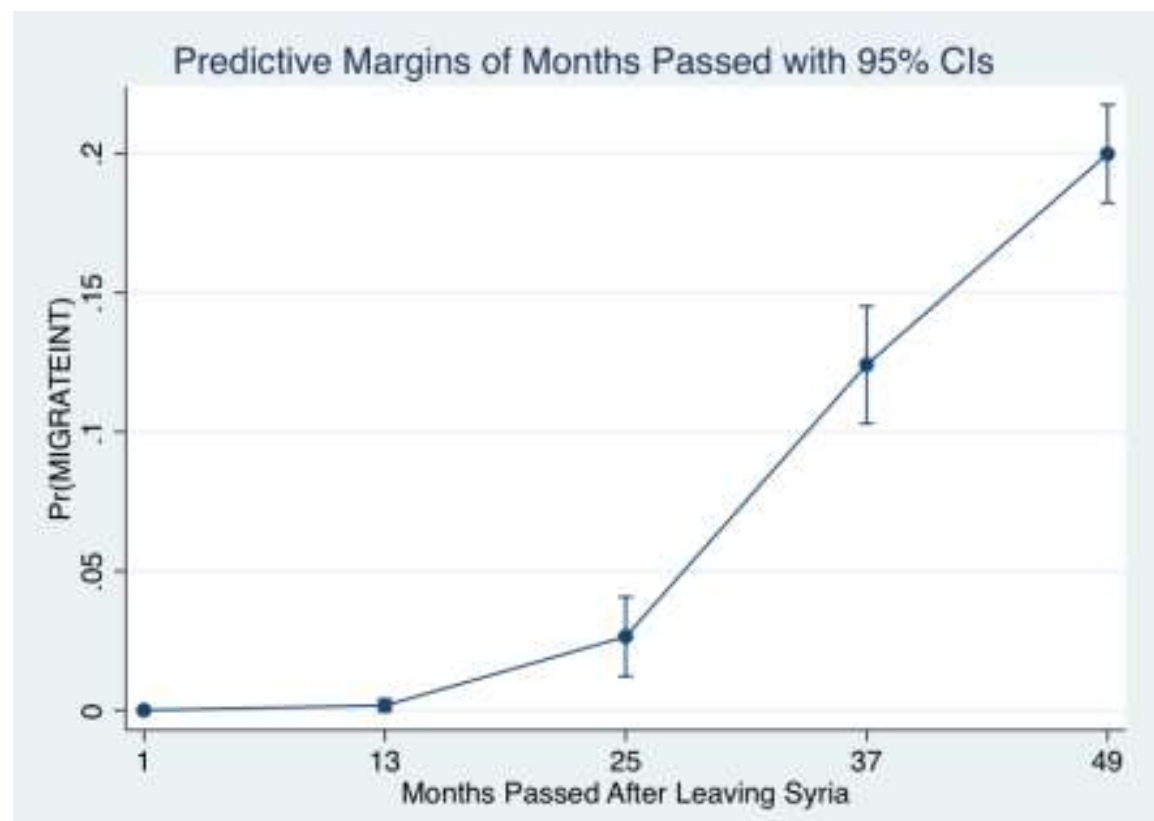

Note: these simulations are based on the estimates reported in column (5) of Table 5.

\section{Conclusions}

By examining the particular effects of the war experiences of individual Syrian refugees living in Turkey based on three waves of the rather remarkable AFAD Survey, this study contributes to that rather thin literature on effects of forced migration at the individual level. Moreover, to our knowledge, it is the first such study to relate these war impacts to subsequent refugee aspirations about returning to their country of origin and migrating elsewhere which are so important for evaluating the long-term consequences of war and the distribution of its costs. To reach such findings, the study includes among the determinants of individual-level migration decisions subsequent to conflict, not only the relatively standard human capital, income, and other demographic characteristics, but also conflict-related measures (such as death of family members and damage to one's home back in Syria), and very importantly also the duration of time lived as a refugee and the quality of services provided to the refugees.

The results show that both the extent and duration of the violence in Syria and the duration of time as a refugee in Turkey raise the probability that a refugee will aspire to permanent settlement in another country and reduce the probability of return to Syria. They also show that the higher the quality of services provided in Turkey to the refugees in the form of health service 
and security, the more likely the refugees will want to stay in Turkey. Moreover, as our robustness checks such as to the relevance of barrel-bombing and other changes in specification indicate, these main results are also quite robust.

Within these general findings are also some interesting special patterns and differences. For example, (1) women refugees are more likely to return back to Syria than males (but apparently only if they are confident that it is safe to do so), and (2) refugees with higher incomes, education, skills, and better access to migration networks are more likely to migrate out of Turkey to Europe and elsewhere.

These explanations of the increasing interest of the refugees to continue to reside outside of Syria rather than to return there either to simply resettle or to fight against Syria's incumbent political regime do not rule out the views expressed by Fabbe et al (2017) and referred to in Section II above that common experience with conflict of the indiscriminate type can induce such refugees to be more cooperative and to want to avoid or even resolve political differences.

The continuing violence in Syria even well after the end of 2015 (covered in the last of the three waves of AFAD Surveys used in this paper), the tragic losses that have been inflicted on the medics and humanitarian suppliers of food and other supplies in Aleppo and other locations in Syria, and even a few tragic events in Turkey, serve to further underscore the likelihood of further violence-caused migration, mental health problems on the part of Syrians affected by the violence $^{16}$ (both refugees and those internally displaced still in Syria), and the ever-increasing costs to aid workers and host populations. This implies that the already high social and economic costs to virtually all parties involved could be increasing for some time to come. ${ }^{17}$

\section{Discussion}

That which has been learned so far from this research has important implications for not only the refugees themselves but also for policies of both the host country to the refugees (in this case Turkey) and the European and other countries to which the refugees might like to move. Among the costs to the host country are not only the costs of taking care of the refugees for which they

\footnotetext{
16 Arslan et al. (2015) have noted an increase of drugs in Hatay, Turkey, near the Syrian border, especially amphetamines, often used by people who are extremely depressed.

${ }^{17}$ While, as indicated above, some analysts have suggested that experience with war can foster cooperative attitudes and behavior, an important meta review by Bauer et al (2016) has concluded that such cooperative attitudes do increase among those within groups, but not between in-groups and out-groups..
} 
may not be receiving full compensation but also those arising from externalities, such as those operating through the labor market, health and other conditions and the prices of food, housing and health care. Especially since Turkey has allowed many of these refugees to work, and to attend schools and gain access to health care, intuition and casual observation would seem to suggest that these costs, too, may be large and rising. Their examination is generally not easy and in any case is well beyond the scope of this paper, as are similar evaluations in Jordan, Lebanon and other countries hosting Syrian refugees. Finally, the longer the war in Syria goes on and the more different ethnic and religious groups involved, it seems to attract more unemployed and depressed Muslims from around the world to come to Syria to fight alongside their chosen group.

Nevertheless, as indicated above, there may be at least a little good news about one important area of such costs on the host population, namely the effects on the local labor markets and the expansion of business enterprises which seem to be much less adverse than in other countries. We suspect that this has been due in part to the relatively better support that Syrian refugees in Turkey have been receiving relative to those in Lebanon and Jordan.

On all these fronts, however, more research is needed, e.g., by including more questions into existing surveys, constructing surveys of very different types concerning the functioning of many different forms of behavior in Turkey influenced by refugees. Especially needed are also periodic updates of the AFAD Survey, converting the AFAD surveys of the Syrian refugees themselves from repeated cross-sections to panel ones, by following the same individuals over time, and by including more questions about the extent to which their Syrian refugee neighbors had been neighbors back in Syria. Since the gradual outflow of Syrian refugees in Turkey to various European countries has introduced a selection bias in the refugees selected for the sample, it would also be highly desirable in that context to be able to sample those already departed refugees. In view of the relatively limited number of individual characteristics controlled for in the present analysis, and the possible relevance of several currently unobserved but potentially important characteristics would be to include in the surveys questions about the religiosity of the individual refugees, the extent to which they may be living near former neighbors and friends from Syria. It would also be desirable to include in any future rounds of the AFAD Survey some key social preferences such as time preference, willingness to bear risk, occupational aspirations and more details about health status, and information about the jobs the refugees find and the earnings they receive, the time and costs of getting to those jobs and the extent to which language or other kinds 
of training they may be receiving may have been contributing to their success in this regard. These are all factors which surveys are capable of capturing.

\section{References}

Adhikari, P. (2013). Conflict-Induced Displacement, Understanding the Causes of Flight. American Journal of Political Science 57, 82-89.

Altindag, O, O. Bakis and S. Rozo, 2017 How Do Refugees Affect Businesses in Developing Countries? The Case of Syrian Refugees in Turkey, University of Southern California.

Alvarado, S. E., Massey, D. S. (2010). In search of peace: Structural adjustment, violence, and international migration. The Annals of the American Academy of Political and Social Science 630, 137-161.

Apodaca, C. (1998). Human rights abuses: Precursor to refugee flight? Journal of Refugee Studies 11, 80-93.

Arslan, M. M., Zeren, C., Celikel, A., Ortanca, I., Demirkiran, S. (2015). Increased drug seizures in Hatay, Turkey related to civil war in Syria. International Journal of Drug Policy 26, 116 118.

Bauer, M., A. Cassar, J. Chytilova, and J. Henrich, (2013) War's Enduring Effects on the Development of Egalitarian Motivations and In-Group Biases. Psychological Science, 25 (1),

Bauer, M., C. Blattman, J. Chytilova, J. Henrich, E. Miguel and T. Mitts 2016. Can War Foster Cooperation?, The Journal of Economic Perspectives 30 (2) 249-274.

Bowles, S. 2008. Being Human: Conflict: Altruism’s Midwife, Nature 456 (7220) 326-7.

Benage, M., Greenough, P. G., Vinck, P., Omeira, N., Pham, P. (2015). An Assessment of Antenatal Care among Syrian Refugees in Lebanon, Conflict and Health 9 (8)

Bohra-Mishra, O., Massey, D. S. (2011). Individual Decisions to Migrate During Civil Conflict. Demography 48, 401-424.

Clark, L. (1989). Early warning of refugee flows. Washington, DC: Refugee Policy Group.

Czaika, M., Kis-Katos, K., (2009). Civil Conflict and Displacement: Village-Level Determinants of Forced Migration in Aceh. Journal of Peace Research 46, 399-418.

Davenport, C. A., Moore, W. H., Poe, S. C. (2003). Sometimes You Just Have to Leave: Domestic Threats and Forced Migration, 1964--1989. International Interaction 29, 27-55. 
Del Carpio, X., Wagner, M. (2015). The Impact of Syrian Refugees on the Turkish Labor Market World Bank Group Policy Research Working Paper 7401.

Doocy, S., Lyles, E., Roberton, T., Akhu-Zaheya, L. Burnham, G. (2015). Prevalence and Careseeking for Chronic Diseases among Syrian Refugees in Jordan, BMC Public Health 15, 1097

Edwards, S. (2009). The Chaos of Forced Migration: A Means of Modeling Complexity for Humanitarian Ends. Saarbriicken, Germany: VDM Verlag.

Engel, S., Ibáñez, A. M. (2007). Displacement due to violence in Colombia: A household-level analysis. Economic Development and Cultural Change 55, 335-365.

Fabbe, K., C. Hazlett, T. Sinmazdemir (2017). Displaced Loyalties: The Effects of Indiscriminate Violence on Attitudes among Syrian Refugees in Turley (2017) No 7 Empirical Studies of Conflict Project.

Hassan, G., Ventevogel, P., Jefee-Bahloul, H., Barkil-Oteo, A., Kirmayer, L. J. (2016). Mental Health and Psychological Wellbeing of Syrians Affected by Armed Conflict. Epidemiology and Psychiatric Sciences 25 (April) 129-141.

Ibáñez, A. M., Vélez, C. E. (2008). Civil Conflict and Forced Migration: The Micro Determinants and Welfare Losses of Displacement in Colombia. World Development 36, 659-676.

Jefee-Bahloul, H., Moustafa, M. K., Shebi, F. M., Barkil-Oteo, A. (2014). Pilot Assessment and Survey of Syrian Refugees Psychological Stress and Openness to Referral for Telepsychiatry (PASSPORT Study) Telemedicine and e-Health 20 (10) 977-9).

Kalyvas, S.(2006). The Logic of Violence in Civil War. Cambridge: Cambridge University Press

Massey, D. S., Williams, N., Axinn, W. G., Ghimire, D. J. (2010). Community services and outmigration. International Migration 48, 1-41.

Matanock, A.M. 2017. Electing Peace: From Civil Conflict to Political Participation. Cambridge: Cambridge University Press.

Melander, E., Öberg, M. (2006). Time to Go? Duration Dependence in Forced Migration. International Inter- actions 32, 129-52.

Melander, E., Öberg, M. (2007). The Threat of Vi- olence and Forced Migration: Geographical Scope Trumps Intensity of Fighting. Civil Wars 9, 156-73.

Moore, W. H., Shellman, S. M. (2004). Fear of Persecution: Forced Migration, 1952-1995. Journal of Conflict Resolution 48, 723-745.

Moore, W. H., Shellman, S. M. (2006). Refugee or Internally Displaced Person? To Where Should One Flee? Comparative Political Studies 39, 599-622.

Moore, W. H., Shellman, S. M. (2007). Whither Will They Go? A Global Study of Refugees' Destinations, 1965-1995. International Studies Quarterly 51, 811-834. 
Marx, A. J. (2016). Detecting urban destruction in Syria: A Landsat-based approach, Remote Sensing Applications: Society and Environment 4, 30-36.

Neumayer, E. (2005). Bogus Refugees? The Determinants of Asylum Migration to Western Europe. International Studies Quarterly 49, 389-409.

Ozden, C., Wagner M. (2014). Immigrants versus Natives?: Displacement and Job Creation World Bank Eorking Paper Series

Ruiz, I., Vargas-Silva, C. (2013). The Economics of Forced Migration Journal of Development Studies 49 (6) $772-784$.

Ruiz, I., Vargas-Silva, C. (2015) The Labor Market Impacts of Forced Migration American Economic Review 105 (5) 581-586.

Schmeidl, S. (1997). Exploring the Causes of Forced Migration: A Pooled Time-Series Analysis, 1971-1990. Social Science Quarterly 78, 284-308.

Shellman, S. M., Moore, W.H. (2007). Whither Will They Go? A Global Study of Refugees' Destinations, 1965-1995. International Studies Quarterly 51, 811-834.

Song, Y. H. (2012). Conflict, International Response, and Forced Migration in Sub-Saharan Africa, 1980-2007. The Korean Journal of International Studies 10, 1-36.

Tyner, E. (2016) Do Territorial Control and the Loss of Territory Determine the Use of Indiscriminate Violence by Incumbent Actors? An Examination of the Syrian Civil War in Aleppo over 45 Weeks, Journal of Terrorism Research 7 (1), 52-66.

Verwimp, P., Maystadt, J-F. (2015). Forced Displacement and Refugees in Sub-Saharan Africa. The World Bank Group, Policy Research Working Paper 7517.

Vogler, M., Rotte, R. (2000). The Effects of Development on Migration: Theoretical Issues and New Empirical Evidence" Journal of Population Economics 13 (3) , 485-508.

World Bank, (2016). MENA Quarterly Economic Brief, January 2016: The Economic Effects of War and Peace. Washington, DC: World Bank. 